\title{
Taxonomy of the Genus Serratia
}

\author{
By P. A. D. GRIMONT, FRANCINE GRIMONT \\ AND H. L. C. DULONG DE ROSNAY \\ Laboratoire de Bactériologie, Université de Bordeaux II, 3, place de la Victoire, \\ Bordeaux 33000, France \\ AND P. H. A. SNEATH \\ Department of Microbiology, University of Leicester, Leicester LEI ${ }_{7} R H$
}

(Received 28 February 1976; revised 25 June 1976)

\begin{abstract}
S UMMARY
One hundred and fifty-six strains of Serratia and related bacteria including representatives of Enterobacter liquefaciens, Enterobacter cloacae, Enterobacter aerogenes, Erwinia carotovora, Erwinia chrysanthemi, Erwinia herbicola and Erwinia nimipressuralis were studied using 223 morphological, physiological, biochemical and carbon source utilization tests. The results were subjected to computer analysis. At the $80 \%$ similarity level all strains, except two, grouped into eight phenons representing: (A) Serratia marcescens with the neotype ССм303 (ATCCI 3880); (B) S. marinorubra with the monotype NCTCI09I2 (ATCC276I4); (CI) $S$. liquefaciens with the type ATCCI $4460 ;\left(\mathrm{C}_{2}\right)$ S. plymuthica with the monotype сCM640 (ATCCI83); (D) Erwinia herbicola with the neotype of Enterobacter agglomerans NCTC938I; (E) Enterobacter cloacae with the neotype NCTCI0005 and Erwinia nimipressuralis; (F) Erwinia carotovora with the type ATCC495, Erwinia atroseptica and Erwinia chrysanthemi; (G) Klebsiella mobilis with the neotype NCTCIO006. At the $70 \%$ similarity level the phenons formed two groups: (A, B, CI, $\mathrm{C} 2)$ and $(\mathrm{D}, \mathrm{E}, \mathrm{F}, \mathrm{G})$.

The following conclusions were drawn. (I) There are three species of enterobacteria producing prodigiosin: $S$. marcescens, $S$. plymuthica and $S$. marinorubra. (2) There are four species of Serratia, one colourless (S. liquefaciens). (3) Subphenons (biovars) are described within the four species of Serratia. (4) Non-pigmented wild-type strains of $S$. marcescens can generally be differentiated from pigmented strains by characters other than pigmentation, because subphenons are homogeneous with respect to pigmentation.

This survey raised some problems of nomenclature because old descriptions could be found that could loosely fit the present phenons. Comparison with an authentic culture was considered to be the most objective way of identifying these phenons with earlier named species.
\end{abstract}

\section{INTRODUCTION}

The taxonomy of the genus Serratia is still confused. At least 42 species names have been associated with the generic name Serratia. Since the early work of Hefferan (1903) several taxonomists have tried to simplify the taxonomy of red-pigmented organisms. The greatest simplification was achieved by Ewing, Davis \& Reavis (I959), Ewing, Davis \& Johnson (I962) and Martinec \& Kocur (I960, I96I $a, b, c, d$ ). Serratia was then a monospecific genus. Besides $S$. marcescens, $S$. marcescens var. kiliensis was retained only because of its negative Voges Proskauer reaction. The only species accepted in the 8th edition of Bergey's Manual of Determinative Bacteriology (Buchanan \& Gibbons, 1974) is S. marcescens. Evidence that there was more than one species of Serratia (Brisou \& Cadeillan, 1959; Fulton, Forney \& 


\section{Table I. Strains studied}

Strains from clinical material are from human sources unless otherwise noted.

$\begin{array}{cc}\text { Strain } & \text { Source* and } \\ \text { Phenon } & \text { nollection no. }\end{array}$

A
Le Minor $18-65$

Le Minor 23-65 Le Minor $19-66$ Brisou

Hôp. Pellegrin Hôp. Pellegrin Lab. Municipal Hôp. Militaire Lab. Municipal Lab. Municipal Lab. Municipal Lab. Municipal Le Minor 8-60 Le Minor 25-60 Le Minor 15-61 Le Minor 29-62 Le Minor 43-62 Le Minor 47-62 Le Minor 62-62 Le Minor I-63 Le Minor I 2-63 Le Minor 27-65 Le Minor 28-65

Le Minor 2-66 Le Minor 1 7-66 Le Minor 20-66 Le Minor 27-66 Le Minor 20-67 Le Minor 25-67 Le Minor 20-68 Le Minor 26-68 Le Minor 33-68 Le Minor 27-69 Le Minor 24-70 Le Minor 28-70 Le Minor 36-70 Le Minor 2-7I Le Minor 6-7I CIP53-85 CIP 53-89 CIP53-100 Sneath Dio6 Sneath D3 8

Brisou 4413 Brisou 5645 Brisou 5568 Brisou 5751 Brisou 6647 Lab. Municipal Lab. Municipal Lab. Municipal Lab. Municipal Lab. Municipal Lab. Municipal Lab. Municipal Le Minor 3-7I Le Minor $14-7 \mathrm{r}$ Veterinary lab. Hôp. Pellegrin CCM3O3

504

506

A2
Names as received and comments

Urine, Pontoise, 1965

Sputum, Lyon, I965

Blood, Nantes, 1966

Pig

Blood, urology ward, 1968

Urine, urology ward, 1968

Effluent water from a distillery, Coutras, 1970

Pus from wound, 1969

Well water, Saint-André-de-Cubzac, 1970

Spring water, Haux, I97 I

Water from a $165 \mathrm{~m}$ boring

Water, 1971

S. marcescens var. kiliensis, ATCC990

S. marcescens var. kiliensis, $\mathrm{CDC}_{574-60}$

Faeces, Strasbourg, I96I

Pasteur Institute, Lyon, 1962

Lepidopteran, Saint-Christol-les-Ales, 1962

Insect, Saint-Christol-les-Ales, 1962

Urine, Pasteur Institute, Lyon, 1962

Blood, Nantes, I963

Urine, Paris, 1963

Blood, Paris, 1965

'Serratia intermédiaire', Chabbert strain CLB

Urine, Pasteur Institute, Lyon, no. 65-083-403 I

Urine, Saint-Etienne, 1966

Urine, Paris, 1966

Urine, Nantes, 1966

Running oedema, Saint-Etienne, 1967

Pork sparerib, Bar-le-Duc, 1967

Urine, Saint-Etienne, 1968

Pasteur Hospital, Paris, 1968

Blood, Suresnes, 1968

Cerebrospinal fluid, Algiers, 1969

Blood, Firminy, 1970

Blood, Arras, I 970

Faeces, Paris, 1970

Lymphatic fluid, Dijon, 197 I

S. marcescens var. kiliensis, ATCC990, Breed BF

S. indica, ATCC4003, Breed $\mathrm{CU}_{37}$

S. marcescens, ATCC8195, Breed HY

Fulton 2690 , Serratia pattern I, pus, 1947

ATCC274, NCTCi 377 , S. marcescens working type (Sneath \& Skerman, 1966)

Sea water, Ré island

River water (Vienne)

River water (Vienne)

River water, Anglin, DSM 30126 , centrotype

River water, Courpiac, 1971

Spring water, $197 \mathrm{I}$

Sea water, Naujac, 197I

Water from a $30 \mathrm{~m}$ boring

River water, $197 \mathrm{I}$

Water from a $640 \mathrm{~m}$ boring, Prayssas, 197 I

Drinking water from a ship, 1971

Blood, Lisieux, 197 I

Blood, Saint-Claude, 197 I

Piglet, Dax, 1972

'Enterobacter liquefaciens', blood, 1972

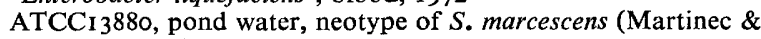
Kocur, I96I $a$ )

Eltinge I 2

'Enterobacter aerogenes', pus, surgery ward, 972 


\section{Table I (cont.)}

\begin{tabular}{|c|c|c|c|}
\hline Phenon & $\begin{array}{l}\text { Strain } \\
\text { no. }\end{array}$ & $\begin{array}{l}\text { Source* and } \\
\text { collection no. }\end{array}$ & Names as received and comments \\
\hline B & $\begin{array}{l}291 \\
294 \\
297 \\
377 \\
378 \\
393 \\
421 \\
511 \\
513 \\
530 \\
540\end{array}$ & $\begin{array}{l}\text { Brisou } 90 \\
\text { Brisou } 658 \\
\text { Santé Navale } \\
\text { Santé Navale } \\
\text { Santé Navale } \\
\text { Lab. Municipal } \\
\text { I.P. Tunis } 8376 \\
\text { I.P. Tunis } \\
\text { Le Minor 4-60 } \\
\text { Le Minor 36-68 } \\
\text { Sneath D 1 19 } \\
\text { Brisou } 641 \\
\text { Brisou } 5648 \\
\text { Brisou 6033 } \\
\text { Lapage T37/66 } \\
\text { Lapage T40/66 } \\
\text { Le Minor } 34-70 \\
\text { I.P. Tunis } \\
\text { CCM788 } \\
\text { NCPPBI } 126 \\
\text { Matsumoto } \\
\text { Le Minor } 34-70\end{array}$ & 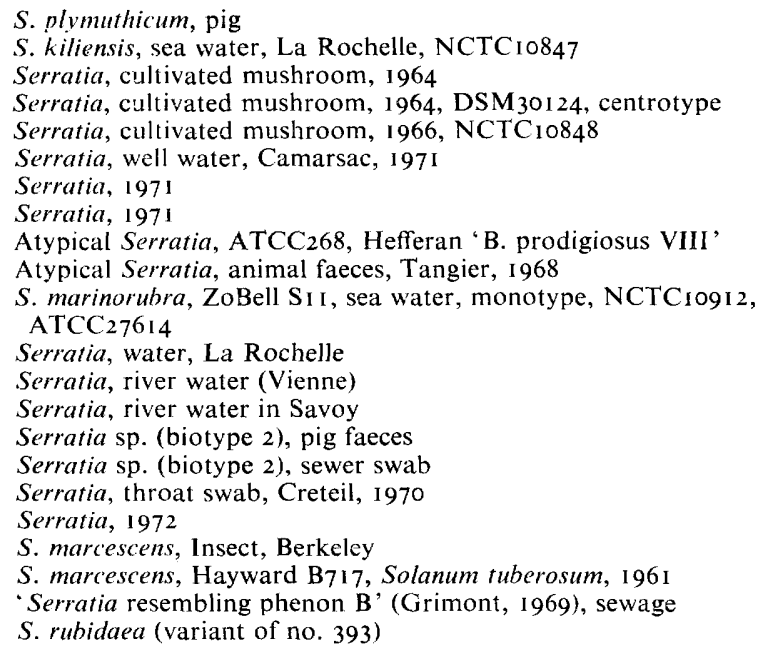 \\
\hline $\mathrm{C}_{\mathrm{I}}$ & $\begin{array}{r}9 \\
221 \\
237 \\
239 \\
271 \\
272 \\
274 \\
275\end{array}$ & $\begin{array}{l}\text { Le Minor Io-66 } \\
\text { Lab. Municipal } \\
\text { Lab. Municipal } \\
\text { Lab. Municipal } \\
\text { Le Minor 3-61 } \\
\text { Le Minor 5-61 } \\
\text { Le Minor 4-68 } \\
\text { Le Minor 5-68 } \\
\text { Le Minor 6-68 } \\
\text { Le Minor 7-68 } \\
\text { Le Minor 8-68 } \\
\text { Le Minor 9-68 } \\
\text { Le Minor } 10-68 \\
\text { Le Minor } 11-68 \\
\text { Le Minor } 12-68 \\
\text { Le Minor } 13-70 \\
\text { Le Minor 2-71 } \\
\text { Le Minor 4-71 } \\
\text { Lab. Municipal } \\
\text { ATCC14460 }\end{array}$ & 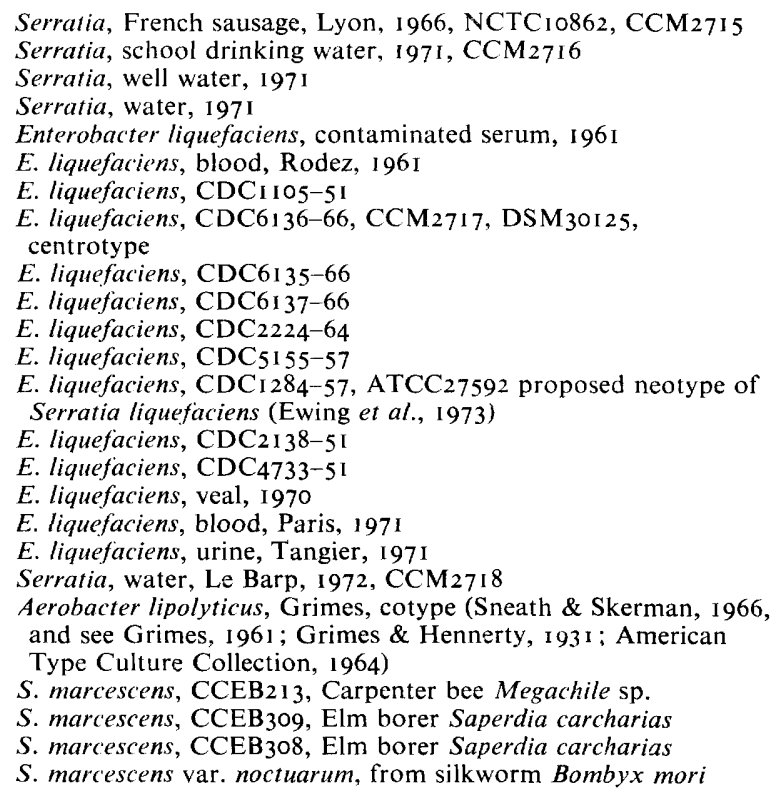 \\
\hline $\mathrm{C}_{2}$ & $\begin{array}{r}33 \\
34 \\
203 \\
235 \\
238 \\
273 \\
289 \\
299 \\
325 \\
329 \\
392 \\
410 \\
500\end{array}$ & $\begin{array}{l}\text { Brisou } 3617 \\
\text { Brisou } 3736 \\
\text { Lab. Municipal } \\
\text { Lab. Municipal } \\
\text { Lab. Municipal } \\
\text { Le Minor 22-61 } \\
\text { Sneath D317 } \\
\text { Brisou 6912 } \\
\text { Lab. Municipal } \\
\text { Lab. Municipal } \\
\text { Lab. Municipal } \\
\text { Lab. Municipal } \\
\text { ATCC } 992\end{array}$ & $\begin{array}{l}\text { S. plymuthicum, sea water, Oléron } \\
\text { S. plymuthicum } \\
\text { Serratia, water, } 1970 \\
\text { Serratia, water, } 197 \text { I } \\
\text { Serratia, water, I97I } \\
\text { 'Atypical E. liquefaciens', Pasteur Institute, Lille } \\
\text { Serratia, NCTC } 9493 \text {, Barrett REXXIVC, water, } 1954 \\
\text { Serratia, sea water, Oléron } \\
\text { Serratia, spring water, Creysse, } 197 \text { I } \\
\text { Serratia, well water, Izon, } 197 \text { I } \\
\text { Serratia, spring water, Bergerac, I97 I, DSM30127, centrotype } \\
\text { Serratia, water supply, } 1972 \\
\text { S. kiliensis, 'B. ruber Kiel isolated by Lubinsky, Kiew' }\end{array}$ \\
\hline
\end{tabular}




\section{Table I (cont.)}

\begin{tabular}{|c|c|c|}
\hline \multirow[t]{2}{*}{ Phenon } & $\begin{array}{c}\text { Strain } \\
\text { no. } \\
501\end{array}$ & $\begin{array}{l}\text { Source* and } \\
\text { collection no. } \\
\text { ATCC426I }\end{array}$ \\
\hline & $\begin{array}{l}502 \\
510 \\
512 \\
515 \\
516 \\
517\end{array}$ & $\begin{array}{l}\text { ATCC7462 } \\
\text { CCM640 } \\
\text { NCIB86I6 } \\
\text { NCIB4612 } \\
\text { NCIB8266 } \\
\text { NCIB8285 }\end{array}$ \\
\hline D & $\begin{array}{l}\text { E2 } \\
\text { EI5 } \\
\text { EI6 } \\
\text { E20 }\end{array}$ & $\begin{array}{l}\text { Hôp. Pellegrin } \\
\text { Lab. Municipa } \\
\text { Lab. Municipal } \\
\text { NCTC938I }\end{array}$ \\
\hline & E23 & Hôp. Pellegrin \\
\hline $\mathrm{E}$ & $\begin{array}{l}\text { E62 } \\
\text { E63 }\end{array}$ & $\begin{array}{l}\text { NCPPB440 } \\
\text { NCPPB2045 }\end{array}$ \\
\hline & $\begin{array}{l}\mathrm{Cl}_{1} \\
\mathrm{C}_{2} \\
\mathrm{C}_{3} \\
\mathrm{C}_{4} \\
\mathrm{C}_{5}\end{array}$ & $\begin{array}{l}\text { CIP6085 } \\
\text { CIP57-33 } \\
\text { CIP68-I } \\
\text { Hôp. Pellegrin } \\
\text { Hôp. Pellegrin }\end{array}$ \\
\hline $\mathbf{F}$ & $\begin{array}{l}\text { E25 } \\
\text { E26 } \\
\text { E27 } \\
\text { E28 } \\
\text { E29 } \\
\text { E30 } \\
\text { E31 } \\
\text { E32 } \\
\text { E33 } \\
\text { E34 }\end{array}$ & $\begin{array}{l}\text { ATCC495 } \\
\text { NCPPB } 312 \\
\text { NCPPB453 } \\
\text { NCPPB } 547 \\
\text { NCPPB } 549 \\
\text { NCPPB929 } \\
\text { NCPPB } 1065 \\
\text { NCPPB } 1066 \\
\text { NCPPB } 1278 \\
\text { NCPPB } 1590\end{array}$ \\
\hline$G$ & AI & CIP60-86 \\
\hline
\end{tabular}

A3 Hôp. Pellegrin

A4 Hôp. Pellegrin

A5 Hôp. Pellegrin

Unclustered

$\begin{aligned} 38 & \text { Santé Navale } \\ 236 & \text { Lab. Municipal }\end{aligned}$

\section{Names as received and comments}

S. kiliensis, Kral collection through Novy. 'Probably an authentic strain of Breunig's original culture isolated from Kiel water, in I 888 ,

S. marcescens var. kiliensis proposed neotype (Martinec \& Kocur, I $96 \mathrm{I} d$ )

S. plymuthica, ATCCI 83 . 'Original strain of Fischer, isolated by him from water supply of Plymouth, England, in I887'

S. kiliensis, Breed K6 (same source as strain 500)

Chromobacterium prodigiosum, strain 'Norfolk Broads'

Chromobacterium prodigiosum, strain $82 \mathrm{~B}$, soil

Chromobacterium prodigiosum, canal water

Erwinia herbicola, blood, I97I

Erwinia herbicola, barley

Erwinia herbicola, spring water

Chromobacterium typhiflavum, laceration of knee, centrotype, neo-

type of Enterobacter agglomerans (Ewing \& Fife, 1972)

Erwinia herbicola, pus, surgery ward, 1972

Erwinia nimipressuralis, Carter, Ulmus sp., 1946

Erwinia nimipressuralis, Carter, Ulmus sp., ATCC991 2, cotype

(Sneath \& Skerman, 1966)

NCTCI0005, ATCCI3047, neotype of Enterobacter cloacae

(Hormaeche \& Edwards, 1960)

NCTC81 55, yellow pigmented Enterobacter cloacae

Enterobacter cloacae, blood, Paris

Enterobacter cloacae, pus, surgery ward, 1972, centrotype

Enterobacter cloacae, urine, 1972

\author{
Erwinia carotovora, soft rot of carrot, Jones, cotype (Sneath \& \\ Skerman, I966) \\ Erwinia carotovora, from Solanum tuberosum \\ Erwinia chrysanthemi, from Dianthus caryophyllus \\ E. carotovora var. carotovora, from Persea americana, centrotype \\ E. carotovora var. atroseptica, from Solanum tuberosum \\ E. carotovora var. carotovora, from Zantedeschia aetiopica \\ Erwinia chrysanthemi, from Zea mays \\ Erwinia chrysanthemi, from Zea mays \\ E. carotovora var. atroseptica, soil \\ E. carotovora var. atroseptica, soil
}

NCTCrooo6, ATCCr 3048. Neotype of Enterobacter aerogenes (Hormaeche \& Edwards, 1960) and of Klebsiella mobilis (Bascomb et al., 1971)

Enterobacter aerogenes, pus, dermatology ward, 1972

Enterobacter aerogenes, urine, urology ward, 1972

Enterobacter aerogenes, pus, haemodialysis unit, 1972, centrotype

Serratia, cultivated mushrooms, 1965, as yet unidentified

Atypical Serratia, water, 1971, now identified as Aeromonas hydrophila

* NCIB, National Collection of Industrial Bacteria, Aberdeen, Scotland. ATCC, American Type Culture Collection, Rockville, Maryland, U.S.A. NCTC, National Collection of Type Cultures, London. NCPPB, National Collection of Plant Pathogenic Bacteria, Harpenden. CCM, Czechoslovak Collection of Microorganisms, Brno, Czechoslovakia. CCEB, Czechoslovak Collection of Entomogenous Bacteria, Prague, Czechoslovakia. CIP, Collection de l'Institut Pasteur, Paris, France. Le Minor, Prof. Le Minor, Institut Pasteur, Paris, France. Lapage, Dr S. P. Lapage, Central Public Health Laboratory, London. Brisou, Prof. J. Brisou, Poitiers University, France. Lab. Municipal, Laboratoire Municipal, Bordeaux, France (R. Serceau). Hôp. Pellegrin, Laboratoire de Bactériologie, Hôpital Pellegrin, Bordeaux, France. Santé Navale, Ecole du Service de Santé des Armées, Bordeaux, France. Veterinary Lab., Centre Véterinaire, Dax, France (Dr Vuillaume). I.P. Tunis, Institut Pasteur de Tunis, Tunis, Tunisia (R. Houissa). Matsumoto, Dr H. Matsumoto, Shinshu University, Matsumoto, Japan. CDC, Center for Disease Control, Atlanta, Georgia, U.S.A. DSM, Deutsche Sammlung von Mikroorganismen, Teilsammlung Weihenstephan, Freising, German Federal Republic. 
Leifson, I959) was not followed up until recently, when Grimont (1969), Bascomb et al. (I97I) and Grimont \& Dulong de Rosnay (I972) produced evidence that red-pigmented enterobacteria constituted more than one species. Although Edwards \& Ewing (1972) had recognized only one species in the genus, Ewing, Davis \& Fife (1972) and Ewing et al. (1973) recognized two species of red-pigmented Serratia, S. marcescens and S. rubidaea.

Relationships between Serratia and Enterobacter liquefaciens were not clear until Hamon, Le Minor \& Peron (I970) showed that S. marcescens and Ent. liquefaciens were sensitive to the same bacteriocins. Close relationship between these two species was so evident in the work of Bascomb et al. (I97I) that they transferred Ent. liquefaciens to the genus Serratia.

The present study was aimed at defining species within Serratia, circumscribing this genus and clarifying its nomenclature.

\section{METHODS}

Strains. These are listed in Table I. Most strains showed colonial variation including pigment-less variants during preliminary culture. A colony of the dominant colonial type (a pigmented colony, if present) was selected for study. The strains were maintained on semisolid nutrient agar containing: meat extract (Leibig), $3 \mathrm{~g}$; yeast extract (Difco), Io g; agar (BBL), $7 \cdot 5 \mathrm{~g}$; distilled water to I 1 ( $\mathrm{pH} 7 \cdot 4)$.

All tests were inoculated from 2-day-old cultures on nutrient agar (as above, but with agar at $\mathrm{I} 5 \mathrm{~g}^{-1}$ ) and incubated at $30^{\circ} \mathrm{C}$ unless otherwise stated. Divided Petri dishes ('replidishes'; Sneath \& Stevens, I967) were used wherever possible, with $3 \mathrm{ml}$ medium per compartment unless otherwise stated. Inoculation of replidishes was as described by Stevens (1969).

Colonial and cell morphology. Bacteria were grown on nutrient agar at $30{ }^{\circ} \mathrm{C}$ for 2 days. Colonial morphology was examined under a magnifying glass $(\times 3)$ and pigment production was noted. Gram-staining was performed at the same time. Odour was noted as being either similar to or different from that of strain 38 (strain 38 had a distinctive odour resembling vegetable matter, unlike the somewhat fishy or faecal odour of most Serratia strains).

Growth in nutrient broth. Nutrient broth (of the same formula as nutrient agar but with the agar omitted) was inoculated and incubated for $24 \mathrm{~h}$. Growth was scored as moderate, dense or very dense.

Solubility and spectral properties of red pigments. Bacteria were grown on peptone/glycerol agar [Bacto-peptone (Difco), $5 \mathrm{~g}$; glycerol, Io $\mathrm{ml}$; agar, $20 \mathrm{~g}$; distilled water, I l], harvested and resuspended in $5 \mathrm{ml}$ acetone. Pigment was extracted by the method of Williams, Green \& Rappoport (1956). Solubility was noted in petroleum ether (b.p. 40 to $60{ }^{\circ} \mathrm{C}$ ) and in water. The pigment which was soluble in petroleum ether was taken to dryness and then dissolved in I I $\mathrm{ml}$ ethanol/I $\mathrm{M}-\mathrm{HCl}(\mathrm{IO}: \mathrm{I}, \mathrm{v} / \mathrm{v})$. Absorption spectra were determined for aqueous and ethanol $/ \mathrm{HCl}$ solutions from 340 to $650 \mathrm{~nm}$. Pigment of strain NIMA (much used in the study of pigment biosynthesis, kindly supplied by Professor R. P. Williams) was used as a control (maximum absorbance at $535 \mathrm{~nm}$, shoulder at $510 \mathrm{~nm}$ in ethanol/ $\mathrm{HCl}$ ).

Growth at different temperatures. Bacteria were incubated in tubes of Trypticase Soy Broth (TSB; BBL) at $5,10,20,37,40,42,45$ and $48{ }^{\circ} \mathrm{C} \pm 0.5{ }^{\circ} \mathrm{C}$. Turbidity was scored visually as slight, moderate, dense or very dense for up to 3 days, or up to Io days, with a photometric reading at $550 \mathrm{~nm}$ on the 1 oth day in the case of growth at $5{ }^{\circ} \mathrm{C}$. Absorbances of less than 0.03 corresponded to visually negative growth. Slight and moderate growth corresponded approximately to absorbances ranging from 0.03 to 0.30 .

$p H$. Ability to grow on TSB at $\mathrm{pH}_{4}, 4.5,5,5.5$ and 9 was recorded every other day for Io days. 
Motility. Tubes containing semi-solid nutrient agar (agar concentration reduced to $0.75 \%$, $\mathrm{w} / \mathrm{v}$ ) were stab inoculated and growth was examined visually for motile swarms for up to 5 days. Motile cultures were stained by the method of Leifson (1960) and examined for flagella at $\times 1000$ magnification.

Growth in the presence of $\mathrm{NaCl}$. Bacteria were incubated in TSB containing 4, 7, 8.5 and $10 \%(\mathrm{w} / \mathrm{v}) \mathrm{NaCl}$ in replidishes. Growth in 4 and $7 \% \mathrm{NaCl}$ was examined visually for up to 2 days. Growth in 8.5 and $10 \% \mathrm{NaCl}$ was examined visually for up to Io days and photometrically on the Ioth day.

Catalase and oxidase tests. One-day nutrient agar cultures were flooded with $\mathrm{H}_{2} \mathrm{O}_{2}$ (10 vols) and oxygen evolution was observed; oxidase was tested by the method of Kovacs (I956).

Growth in the presence of $K C N$. $\mathrm{KCN}$ medium (BBL) supplemented with $\mathrm{KCN}\left(75 \mathrm{mg} \mathrm{1}^{-1}\right.$ ) and triphenyltetrazolium chloride $\left(50 \mathrm{mg} \mathrm{l}^{-1}\right)$ was inoculated, layered with paraffin oil and examined after 5 and Io days for red insoluble formazan. A control medium without $\mathrm{KCN}$ was included.

Nitrate reduction. Bacteria were incubated in nitrate broth [Bacto-peptone (Difco), $5 \mathrm{~g}$; glucose, $0 . \mathrm{I} \mathrm{g}$; $\mathrm{KNO}_{3}$, I $\mathrm{g}$; distilled water, I $1(\mathrm{pH} 7 \cdot 4)$ ] for 2 days and tested for nitrate by adding Griess-Ilosvay reagents. Negative results were checked by adding zinc powder (ZoBell, 1932).

Growth in the presence of $\mathrm{KClO}_{3}$. VL agar [tryptone (Difco), Io g; $\mathrm{NaCl}, 5 \mathrm{~g}$; meat extract (Liebig), $2 \mathrm{~g}$; yeast extract (Difco), $5 \mathrm{~g}$; cysteine hydrochloride, $0.3 \mathrm{~g}$; glucose, $2 \mathrm{~g}$; Bactoagar (Difco), $6 \mathrm{~g}$; distilled water, I 1 ( $\mathrm{pH}_{7 \cdot 4}$ )] supplemented with $0.1 \%$ (w/v) $\mathrm{KClO}_{3}$ was dispensed into tubes ( $160 \times 10 \mathrm{~mm}$ ) to give a column $70 \mathrm{~mm}$ deep, and inoculated from an overnight culture in TSB diluted $\mathrm{I}: 20$. A control tube without $\mathrm{KClO}_{3}$ was also inoculated. Nitrate reductase A reduces chlorate anaerobically to hypochlorite which inhibits growth in the depths of the tube, whereas nitrate reductase B does not reduce chlorate, so that growth occurs throughout the tube as in the control (Pichinoty \& Piéchaud, 1968). Strains unable to reduce nitrate (though they grew in the presence of $\mathrm{KClO}_{3}$ ) were scored as 'no comparison'.

Tetrathionate reduction. The liquid medium of Le Minor et al. (1970) was sterilized by filtration, and then dispensed into tubes ( $120 \times 12 \mathrm{~mm})$, inoculated and incubated overnight. Unequivocal acidification was scored as positive. Negative tubes were read again at 2 days.

Voges Proskauer test. Clark and Lubs medium (BBL) was used. The test was carried out in three ways: (i) in test tubes $(5 \mathrm{ml})$ tested for production of acetoin after 3 days incubation by the method of Barritt (I936); (ii) in replidishes ( $.5 \mathrm{ml}$ ) tested after 3 days by the method of O'Meara (I93 I); and (iii) in replidishes $(0.5 \mathrm{ml})$ tested after overnight incubation (Richard, I972) with addition of $0.5 \mathrm{ml} \alpha$-naphthol solution and $0.5 \mathrm{ml} 4 \mathrm{M}-\mathrm{NaOH}$. Acetoin is rapidly produced and detected by Richard's method. Some strains may quickly destroy acetoin and butanediol and thus give a negative reaction after the longer incubation which is necessary with the other two methods. The Richard and O'Meara tests may thus detect different characters of some strains, and so were scored separately.

Methyl red test and final $\mathrm{pH}$ measurements. Cultures were grown in Clark and Lubs medium (BBL) in test tubes for 3 days. $\mathrm{pH}$ was determined using 'Lyphan' $\mathrm{pH}$ indicator paper (G. Kloz, West Berlin). About $0^{\cdot} \mathrm{I} \mathrm{ml}$ of each culture was placed in a well of a microtitre plate and a drop of methyl red solution was added. Positive, doubtful and negative results corresponded respectively to the following $\mathrm{pH}$ ranges: $5 \cdot 2$ or below, 5.5 to $5 \cdot 8$, and 6. I or above.

Gas from glucose. Nutrient agar supplemented with $\mathrm{I} \%(\mathrm{w} / \mathrm{v})$ glucose was dispensed into tubes $(160 \times 10 \mathrm{~mm})$, inoculated when molten and examined for bubbles of gas for up to 3 days. 
Oxidative/fermentative utilization of glucose. The medium and method of Hugh \& Leifson (1953) was used.

Production of acid from carbohydrates. To peptone water [Bacto-peptone (Difco), Io g; $\mathrm{NaCl}, 5 \mathrm{~g}$; distilled water, I 1 ( $\mathrm{pH} 7 \cdot 4$ )] containing bromothymol blue solution ( $2 \mathrm{ml} \mathrm{1}^{-\mathbf{1}}$ : bromothymol blue, $0.2 \mathrm{~g}$; O.I M-NaOH, $5 \mathrm{ml}$; distilled water, $95 \mathrm{ml}$ ), carbohydrates were added to give a final concentration of $0.5 \%(\mathrm{w} / \mathrm{v})$. Replidishes were examined for acidification for up to 5 days.

Gluconate test. Bacteria were incubated in the medium of Haynes (1951) for 2 days and the presence of reducing derivatives was tested by adding a Clinitest tablet (Ames Co., Slough). Colours ranging from light green to rusty yellow were scored as positive whereas a deep blue colour was scored as negative.

Iodoacetate test. The medium of Lysenko (196I) was sterilized by boiling for $30 \mathrm{~min}$ on three successive days, then supplemented with sodium iodoacetate (sterilized by filtration) at $208 \mathrm{mg} \mathrm{l}^{-1}$. Cultures in this medium were examined for acid production for 5 days. Controls without iodoacetate were included.

Ammonia from peptone. Peptone water was dispensed into test tubes and inoculated. After 5 days incubation ammonia was detected by a spot test on a filter paper impregnated with Nessler reagent. Production of an orange to brown colour was scored as positive.

Hydrogen sulphide production. Peptone water supplemented with $0.0 \mathrm{I} \%(\mathrm{w} / \mathrm{v}) \mathrm{L}$-cysteine hydrochloride $(\mathrm{BDH})$ was inoculated. Lead acetate paper was placed in the lid of the dish to cover all compartments (Stevens, 1969) and was observed for blackening for 5 days. Doubtful results were repeated in tubes with strips of lead acetate paper inserted between the cotton plug and the tube.

Production of indole from peptone. Peptone water was dispensed in tubes and inoculated. Indole was detected with Kovacs' reagent after I and 6 days incubation. Positive results with pigmented strains were checked by using Difco indole test strips inserted between the cotton plug and the tube. Some precursors of prodigiosin (either volatile or not) may react with Ehrlich reagent (contained in Kovacs' reagent and on Difco indole test strips), so by 'indole' we mean an 'Ehrlich positive substance'.

Lysine, ornithine and arginine decarboxylases. Møller's medium (Møller, 1955) for decarboxylases (BBL) supplemented with either lysine, ornithine or arginine (I \%, w/v) was inoculated and covered by a layer of paraffin oil. Compartments were examined for alkalinization for 4 days. Activity of arginine decarboxylase is not distinguished from that of arginine dihydrolase by this medium.

Deamination of phenylalanine. Medium [yeast extract (Difco), $3 \mathrm{~g}$; DL-phenylalanine, $2 \mathrm{~g}$; $\mathrm{Na}_{2} \mathrm{HPO}_{4}$, I g; NaCl, $5 \mathrm{~g}$; Bacto-agar (Difco), I $2 \mathrm{~g}$; distilled water, I 1] was inoculated and incubated for 2 days. Aqueous ferric chloride solution ( $13 \%$ w/v) was then added dropwise to the compartments and development of a green colour was read as positive.

Urease. The liquid medium of Stuart, Van Stratum \& Rustigian (1945), sterilized by filtration, was inoculated and examined daily for alkali production for up to Io days.

Malonate. Bacto-malonate broth (Difco) was inoculated and examined for alkalinity after 4 and 8 days. Cultures giving late positive results were retested in tubes.

Gelatin hydrolysis. Two methods were used. (1) Nutrient gelatin [Bacto-peptone (Difco), $5 \mathrm{~g}$; meat extract (Liebig), $3 \mathrm{~g}$; gelatin, I $20 \mathrm{~g}$; distilled water, I l] was dispensed in small tubes, inoculated and incubated at $20^{\circ} \mathrm{C}$; liquefaction was recorded after $\mathrm{I} 5$ days. (2) $\mathrm{Nu}$ trient agar containing $4 \%(\mathrm{w} / \mathrm{v})$ gelatin was poured into square Petri dishes $(9.5 \times 9.5 \mathrm{~cm})$ and inoculated ( 25 strains per dish). Zones of hydrolysis were detected by flooding with 
aqueous mercuric chloride (I0 \%,w/v) after incubation at $30{ }^{\circ} \mathrm{C}$ for I day. Negative strains were retested after 4 days incubation.

Chitin hydrolysis. Colloidal chitin was prepared by dissolving $2 \mathrm{~g}$ chitin (Fluka, Buchs, Switzerland) in $40 \mathrm{ml}$ cold I I $\mathrm{M}-\mathrm{HCl}$, allowing the solution to stand for $3 \mathrm{~h}$ and then filtering it through glass wool. The filtrate was diluted $\mathrm{I}$ : Io in cold distilled water, and the precipitate was washed three times with distilled water, suspended in distilled water, neutralized with $0 \cdot \mathrm{I} \mathrm{M}-\mathrm{NaOH}$, and again washed three times with distilled water. The chitin was then suspended in $40 \mathrm{ml}$ distilled water, sterilized by heating at $80^{\circ} \mathrm{C}$ for $30 \mathrm{~min}$ on three successive days, then added to molten nutrient agar to a final concentration of $4 \%(\mathrm{w} / \mathrm{v})$. After inoculation and incubation, plates were examined for up to 5 days for clearing around the growth.

Tributyrin hydrolysis. Tributyrin was suspended in nutrient agar following the method of Hugo \& Beveridge (1962). After inoculation and incubation, plates were observed for clearing for up to 15 days.

Acid from triacetin. The method of Hugo \& Beveridge (1962) was used. Cultures were examined for acidification for up to 5 days.

Tween hydrolysis. Tween 40,60 and 80 (Sigma), at final concentrations of $\mathrm{I} \%(\mathrm{v} / \mathrm{v})$, were added to medium [Bacto-peptone, $10 \mathrm{~g} ; \mathrm{NaCl}, 5 \mathrm{~g} ; \mathrm{CaCl}_{2} . \mathrm{H}_{2} \mathrm{O}, \mathrm{o} \cdot \mathrm{I} \mathrm{g}$; agar (BBL), I5 g; distilled water, I 1 ( $\mathrm{pH} 7 \cdot 4$ )], and dispensed into square Petri dishes and multi-inoculated (25 strains per plate) with about $0.02 \mathrm{ml}$ of an $\mathrm{I} 8 \mathrm{~h}$ culture in TSB. Zones of precipitation were recorded for 5 days.

Lecithinase. A $2 \%(\mathrm{w} / \mathrm{v})$ sterile alcoholic solution of lecithin (Sigma) was diluted $\mathrm{I}: 3$ in water, then sonicated briefly. The opalescent emulsion was added to nutrient agar ( $5 \%, \mathrm{v} / \mathrm{v})$ and dispensed as for Tween hydrolysis. Precipitation around colonies was recorded for up to 5 days.

Starch hydrolysis. Nutrient agar containing $0.5 \%(\mathrm{w} / \mathrm{v})$ soluble starch (Fluka) was used. Plates were flooded with Lugol's iodine and examined for clear zones after 4 days.

Deoxyribonuclease. Bacteria were grown on DNAase medium (BBL). After 3 days the plates were flooded with $\mathrm{I} \mathrm{M}-\mathrm{HCl}$ and inspected for areas of clearing. The test was repeated for negative strains after 5 days incubation.

Pectin hydrolysis. Minimal medium M70 (Véron, 1975) supplemented with $0.5 \%(\mathrm{w} / \mathrm{v})$ citrus pectin (Sigma) and $0.1 \%(\mathrm{w} / \mathrm{v})$ yeast extract (Difco) was used. After 5 days incubation, plates were flooded with a $\mathrm{I} \%(\mathrm{w} / \mathrm{v})$ aqueous solution of Cetrimide and examined for clear zones (Hankin, Zucker \& Sands, I97I).

$\beta$-Galactosidase. Sterile microtitre plates were used. Overnight cultures on nutrient agar supplemented with I \% (w/v) lactose were suspended in distilled water and dispensed into

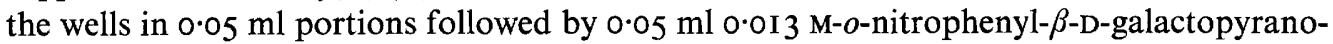
side (Sigma) in 0.25 M-phosphate buffer $\mathrm{pH} 7$ (Le Minor \& Ben Hamida, 1962). Cetrimide $(0.025 \mathrm{ml} ; 0.001 \%$, w/v) was added in place of toluene (Reeves \& Braithwaite, 1972). A control well with $0.05 \mathrm{ml}$ distilled water instead of bacteria was included. Plates were incubated and examined for a yellow colour after $90 \mathrm{~min}$. Negative strains were retested in tubes and examined for up to $24 \mathrm{~h}$.

$\beta$-Xylosidase. The method of Brisou, Richard \& Lenriot (1972) was adapted for use with sterile microtitre plates. Aqueous (I \%,w/v) $p$-nitrophenyl- $\beta$-xyloside was dispensed into the wells in $0.05 \mathrm{ml}$ portions, followed by $0.05 \mathrm{ml}$ of a fresh bacterial suspension in $0.25 \mathrm{M}$ phosphate buffer $\mathrm{pH} 7$. Plates were examined for a yellow colour after $24 \mathrm{~h}$.

Thallous acetate resistance. Mueller Hinton agar (Difco) supplemented with thallous 
acetate was dispensed and inoculated as described for Tween hydrolysis. Growth was recorded daily for 7 days.

Cetrimide resistance. Mueller Hinton agar (Difco) supplemented with Cetrimide was dispensed, inoculated, and examined as for Tween hydrolysis.

Tetracycline resistance. Mueller Hinton agar (Difco) containing tetracycline, dispensed as described for Tween hydrolysis, was inoculated with diluted I $8 \mathrm{~h}$ TSB cultures [one platinum loop (diam. $3 \mathrm{~mm}$ ) of culture in $10 \mathrm{ml}$ distilled water]. Growth was recorded after $\mathrm{I} 8 \mathrm{~h}$.

Colistin resistance. Mueller Hinton agar (Difco) supplemented with colistimethate (Sigma) was dispensed, inoculated and examined as for tetracycline resistance.

Carbon source utilization tests. Defined medium M70 (Véron, 1975) was used. Carbohydrates (final concentration $0.2 \%, \mathrm{w} / \mathrm{v}$ ), phenol (final concentration $0.025 \%, \mathrm{w} / \mathrm{v}$ ) and other carbon sources (final concentration $0.1 \%$, w $/ v$; only anion considered for organic acids) were added as required. Alcohols, strongly acidic or alkaline carbon sources were handled aseptically and added to the molten hot medium. Insoluble carbon sources were heated at $80^{\circ} \mathrm{C}$ for $20 \mathrm{~min}$. Aqueous solutions of other carbon sources were filtered. The $\mathrm{pH}$ was adjusted to $7 \cdot 2$ if necessary. Sterility controls were included. Dispensed media were allowed to dry overnight at $37^{\circ} \mathrm{C}$. Inocula were obtained by washing I-day-old culture from a nutrient agar slant (2-day-old for pectobacteria) with $10 \mathrm{ml}$ sterile distilled water. Growth was recorded every other day for up to I 6 days. Plates without carbon source served as controls for background growth. Plates with glucose as sole carbon source were included to check the viability of bacterial suspensions.

Carbon sources deleted from the study because growth on them was too often scored as 'doubtful' were amygdalin, D-arabinose, starch, maleate, malonate, 2-hydroxybenzoate, glycine, L-lysine, L-threonine, ethanolamine and hypoxanthine.

Coding of characters. All tests were scored as I or o on two columns in order to give equal weight to quantitative as well as qualitative characters. Carbon source utilization tests were scored as follows: o, o (negative); I, o (late positive); or I, I (early positive). Tests that clearly showed two grades of reaction were scored in the same way. The Richard and O'Meara methods for the Voges Proskauer test were scored as above. Results of growth at different temperatures, $\mathrm{pH}$ and $\mathrm{NaCl}$ concentrations required more than two columns. They were coded additively (Sneath \& Sokal, I973) with two columns for the upper limit for pH, three columns for the lower limit for temperature, and four columns for the upper limit for temperature, the lower limit for $\mathrm{pH}$ and for growth in $\mathrm{NaCl}$. Inapplicable or missing test results were scored 'no comparison' (NC).

Carbohydrate fermentation tests, which almost duplicated the corresponding carbon source utilization tests as regards ability to metabolize individual carbohydrates, were not included. Each culture was derived from a single selected colony, and because there may have been bias in choosing the colonies according to their appearance, colonial characteristics were omitted. Invariant character states were deleted before computation.

Computation. The simple matching coefficient, $S_{S M}$, of Sokal \& Michener (I958) was computed and strains were clustered using both single linkage (Sneath, 1957) and the unweighted pair group method with averages (UPGMA; Sokal \& Michener, 1958). Vigour and pattern statistics (Sneath, I968) were also calculated. Centroids of the phenons formed at the $80 \%$ similarity level by UPGMA were calculated, and the distribution of distances, $d=\sqrt{ }\left(\mathrm{I}-S_{s M}\right)$, of strains from the centroid of their own phenon was determined. The mean and standard deviation of these distances, $\bar{d}_{c j}$ and $s_{d c j}$, were then calculated. The limits of phenons are to some degree arbitrary because one can choose an envelope that encloses any given proportion of the strains of the phenon. The envelope chosen here is one that will in 
theory enclose $97.5 \%$ of strains of a phenon (assuming that the phenons are hyperspherical multivariate normal clusters, an assumption that appears to be a reasonable approximation, see Sneath, 1974). The envelope is defined by a radius, $r_{J}$, about the cluster centroid that equals $\bar{d}_{c j}+k s_{d c j}$ with $k=\mathrm{I} \cdot 96$. This gives a measure of the dimension (dispersion) of the cluster (there are some sources of bias in these estimates when the number of strains is very small, but the practical effects in the present study are of little consequence).

The estimation of overlap between clusters is a complex problem that has not been satisfactorily explored: it will not be considered in detail here. A rough indication of the overlap was obtained from histograms of the distances of strains from the centroids (Sneath, 1972) and showed that the clusters are well separated.

\section{RESULTS}

All the strains in the study were Gram-negative, straight rods with rounded ends, catalase positive, utilized glucose by fermentation, and utilized $\mathrm{N}$-acetylglucosamine, aspartate, citrate, D-fructose, gluconate, D-glucose, L-malate, mannitol and D-ribose as sole carbon sources. Though all strains utilized gluconate for growth, not all produced detectable amounts of reducing compounds, possibly because in these cases the gluconate was catabolized by a different pathway (Fraenkel \& Vinopal, 1973).

All strains were negative for the following tests: growth at $\mathrm{pH} 4$; phenylalanine deaminase; urease; growth on acetamide, adipate, 4 -aminobenzoate, DL- $\delta$-aminovalerate, $\alpha$-amylamine, azelate, benzylamine, butanol, isobutanol, isobutyrate, butylamine, citraconate, DLcitrulline, creatine, dulcitol, ethylene glycol, D-fucose, glycollate, L-leucine, L-isoleucine, DL-norleucine, laevulinate, D-mandelate, L-mandelate, mesaconate, methanol, methylamine, oxalate, pantothenate, phenol, phthalate, isophthalate, terephthalate, pimelate, propanol, isopropanol, propylene glycol, sebacate, spermine, suberate, testosterone, tryptamine, D-tryptophan, uracil, urea, isovalerate, L-valine, and L-xylose as sole carbon source.

\section{Clustering}

Clustering by unweighted average linkage (UPGMA) yielded eight phenons at the $80 \%$ similarity (S) level (Fig. I). The co-phenetic correlation, i.e. the correlation between the original similarity values and those shown in the phenogram, was 0.90 , which was satisfactory. Characteristics of the phenons are given in Table 2. The relationships between phenons are not quite the same as those in earlier studies (Grimont, 1969; Grimont \& Dulong de Rosnay, 1972) but to avoid confusion the same symbols have been retained here where applicable: this mainly affects the position of phenon $\mathrm{B}$.

Phenon A. This contained 62 strains and could be subdivided (Fig. I) into I I subphenons (AI to AI I) though some are dubious: A7 was composed of strains 24I and 284 both derived from ATCC990; Alo comprised two strains, one of which (242) was scored as 'no comparison' for all carbon sources; using the pattern coefficient, subphenons A9 and AII disappeared and their component strains were included in other subphenons. Seven subphenons may be taxonomically significant; the tests that differentiate them are given in Table 3 . These subphenons were homogeneous with respect to red pigmentation. The pigments were non-diffusing but soluble in petroleum ether, and their visible spectra were similar to that of the pigment prodigiosin from strain NIMA which we have recently determined to be a typical strain of subphenon A2.

Phenon A corresponds to Serratia marcescens [the neotype suggested by Martinec \& Kocur (I96I $d$ ) is strain 504] and also to Serratia pattern I of Fulton et al. (1959), to the 
single Serratia phenon of Colwell \& Mandel (1965), to Serratia biotype I of Bascomb et al. (197I, 1973) and to phenon A of Grimont \& Dulong de Rosnay (1972), as shown by the inclusion in phenon A of strains 287, 504, 290 and 5. We have recently identified $S$. indica (Eisenberg, 1886) Bergey et al. 1923 (monotype CIP53-98, ATCC4002) and Erythrobacillus pyosepticus Fortineau 1904 (monotype CIP53-91, ATCC275) as both belonging to subphenon AI. Strain ATCC8I I I [labelled S. marcescens subsp. kiliensis in the American Type Culture Collection (1974) catalogue also belongs to phenon A. Later three strains of $S$. anolium Duran-Reynals and Clausen 1937 (B-1700 from the Northern Regional Research Laboratory, Peoria, Illinois, U.S.A., and s-4 and s-19 from the Division of Applied Biology, National Research Council of Canada, Ottawa, Canada) were found to belong to subphenon A4 although they produce very little pigment.

Phenon $B$. This contained 22 pigmented strains. Three subphenons were observed; their differential characteristics are given in Table 4 . The pigments of all these strains were soluble in petroleum ether and gave spectra identical to that of prodigiosin from strain NIMA.

Phenon B corresponds to Serratia marinorubra, Serratia biotype 2 of Bascomb et al. (197I) and to phenon B of Grimont \& Dulong de Rosnay (1972), as shown by the inclusion of strains 288, 377 and 20 . We have recently studied the proposed neotype of Serratia rubidaea (see Discussion), CDC2 199-72, and identify it as a strain of subphenon B2; its pigment is also indistinguishable from prodigiosin.

Phenon $C$ I. Phenon Cr contained 24 non-pigmented strains, and was subdivided into four subphenons, whose differential characteristics are shown in Table 5. This phenon corresponds to Enterobacter liquefaciens (Grimes \& Hennerty, 1931; Ewing, 1963) and to Serratia liquefaciens of Bascomb et al. ( I 971). It also corresponds to Serratia ecogroup V of Lockhart \& Hartman (1963) and to part of phenon C of Grimont \& Dulong de Rosnay (1972) as shown by the inclusion of strains of those groups. It also contained the strain received as Serratia marcescens var. noctuarum (strain 5 I4). We have recently identified another strain of Grimes and Hennerty, ATCCI446I, as a member of subphenon CId (see Discussion).

Phenon C2. This contained 20 strains. Most were isolated from water and all but two produced red pigment. The pigments of all except one strain were soluble in petroleum ether, and the spectra were similar to that of prodigiosin from strain NIMA. Strain 329 was exceptional in producing a pigment soluble in water, but not in petroleum ether or benzene, showing maximum absorbance at $496 \mathrm{~nm}$ and a shoulder at $535 \mathrm{~nm}$. There were three subphenons (Table 6).

Phenon C2 corresponds to Serratia plymuthica (Fischer's Plymouth bacillus), S. kiliensis (Breunig's Kiel bacillus), $S$. marcescens var. kiliensis of Martinec \& Kocur (I96I $d$ ) and to part of phenon C of Grimont \& Dulong de Rosnay (1972), as shown by the inclusion of strains 5IO, 50 I, 502, 33 and 34. The atypical strains of Colwell \& Mandel (I965), strains 500 and 50 I, also labelled Serratia III by Mandel \& Rownd (I964), fell into this phenon, as did a strain which we have subsequently studied, CDCI 2 I0-70 (ATCCI5928), that was reported by Ewing et al. (1973) to be an atypical strain of Serratia rubidaea (see Discussion). Four NCIB strains $(5 \mathrm{I} 2,5 \mathrm{I} 5,5 \mathrm{I} 6,5 \mathrm{I} 7)$ that were noted in the catalogue of the National Collection of Industrial Bacteria (1964) as being unclassifiable by the scheme of Ewing et al. (I973), fall into phenon $\mathrm{C} 2$.

We have recently found that the monotype of Serratia esseyana Combe 1933 (NCTC4618) falls into phenon $\mathrm{C} 2$. Although strains labelled $S$. kiliensis or S. marcescens var. kiliensis belonged to phenon $\mathrm{C} 2$, strain 242, identified by Ewing et al. (I962) as $S$. marcescens var. kiliensis on the sole basis of a negative Voges Proskauer reaction, clustered in phenon A.

Phenons A to C, comprising the Serratia-Enterobacter liquefaciens group, clustered at the 


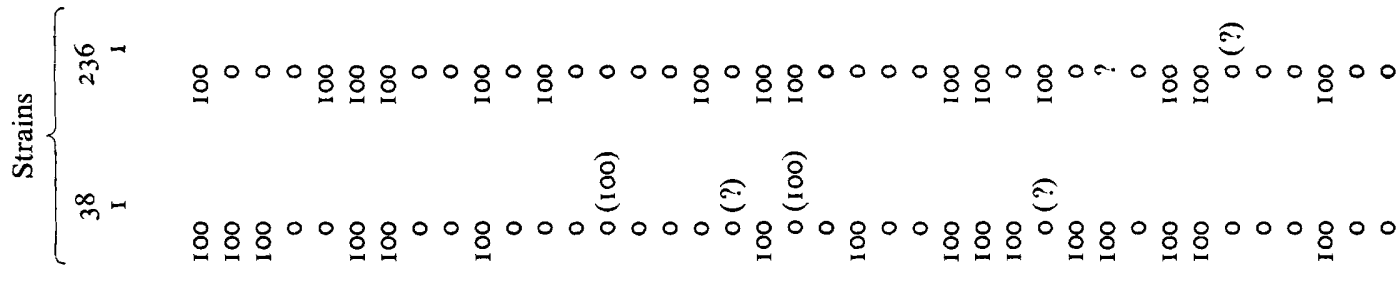

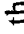

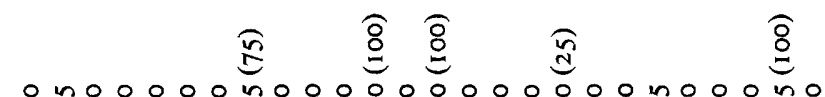

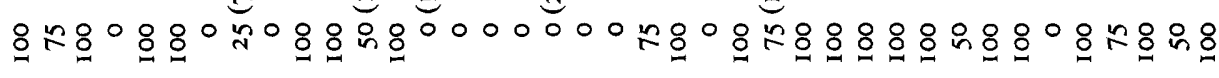

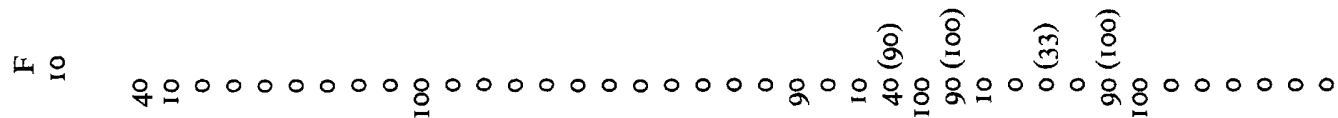

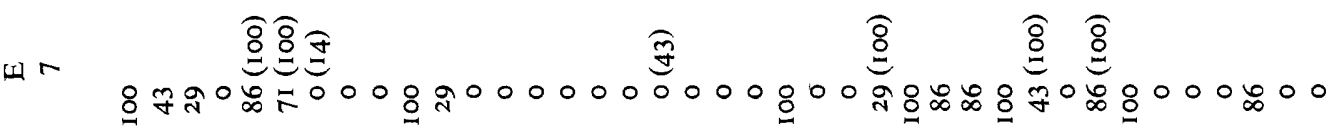

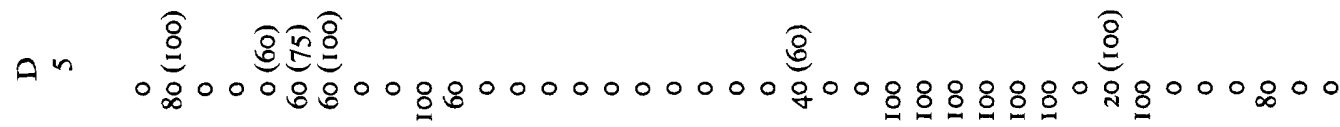

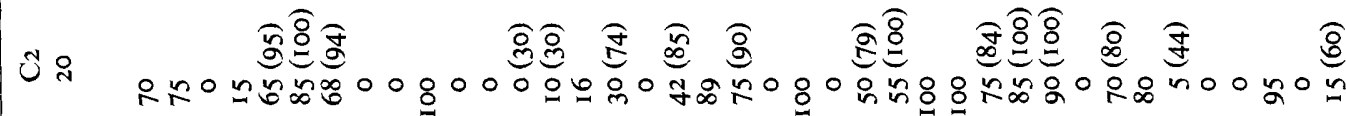
च

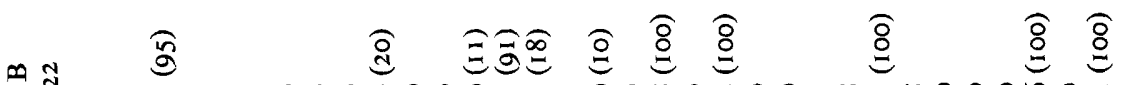

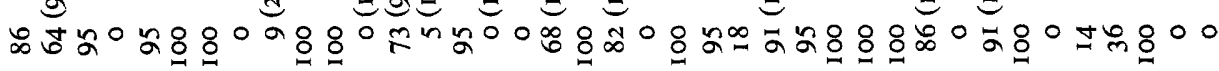

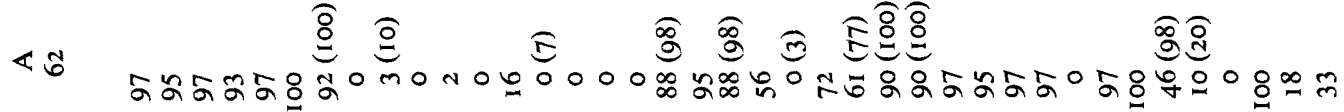

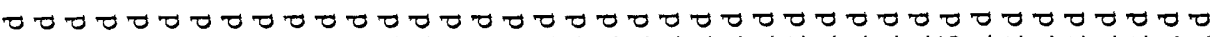

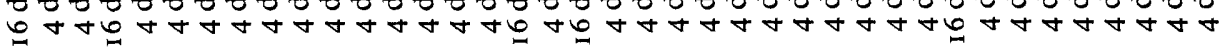

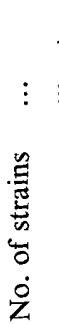

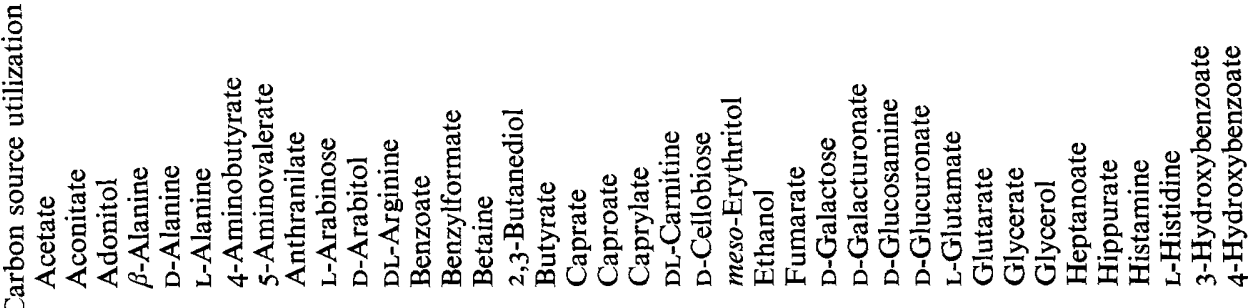

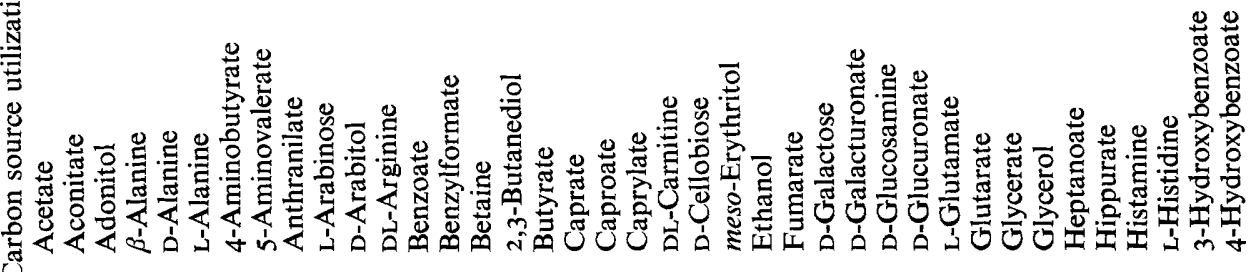




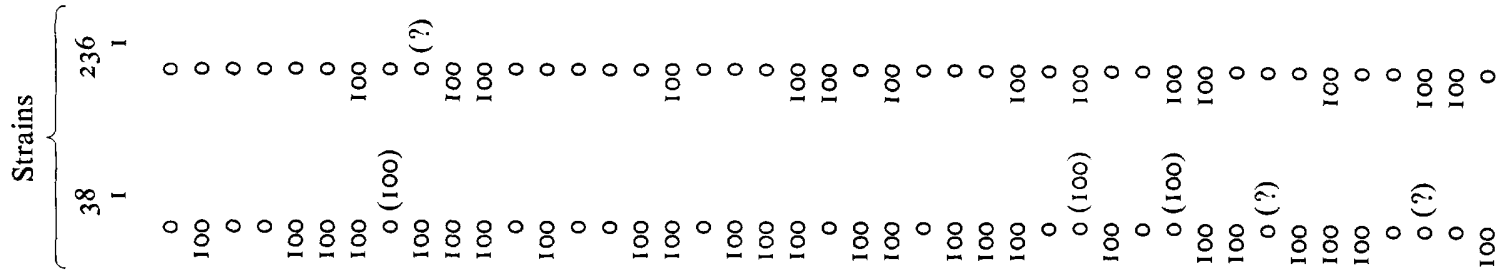

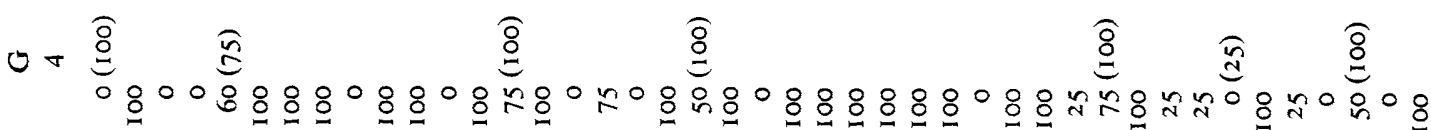

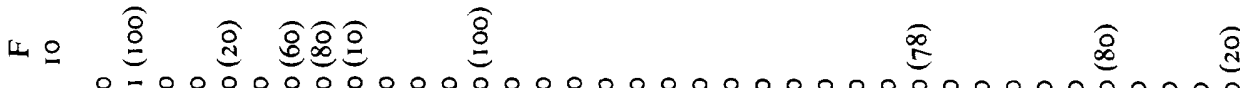

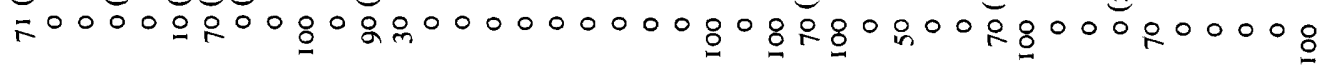

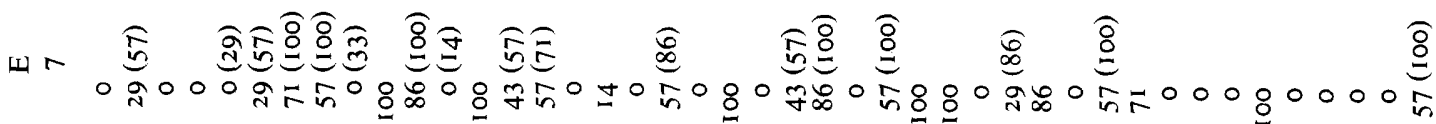

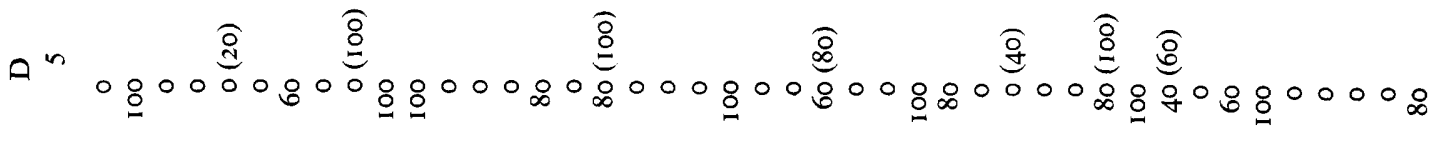
Uं

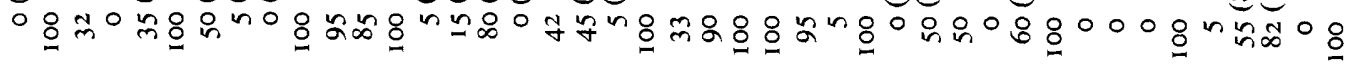

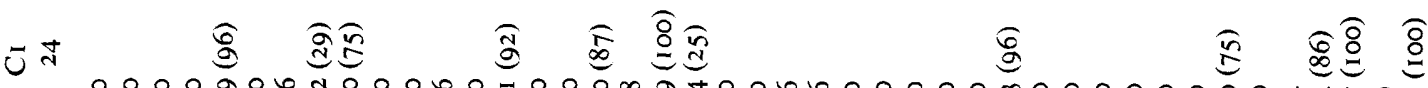

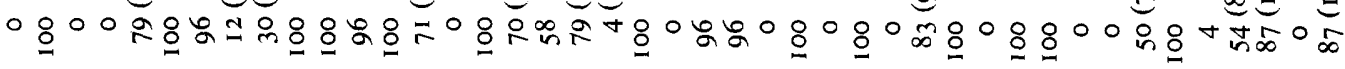

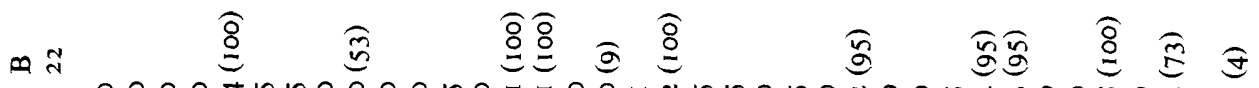

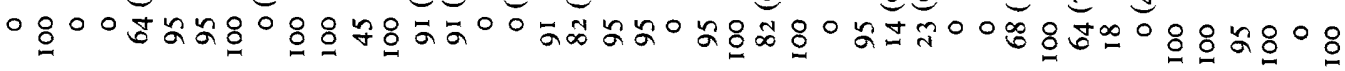

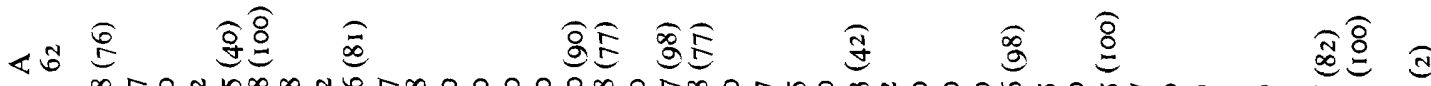

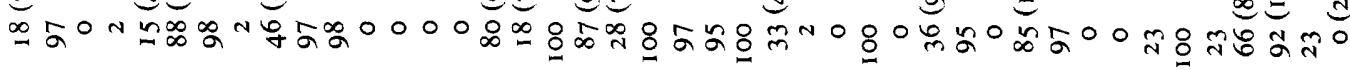

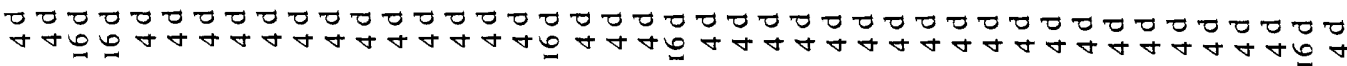

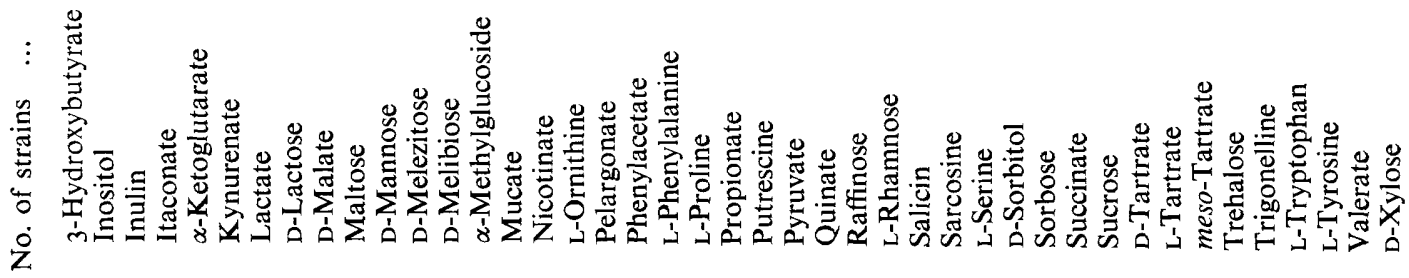




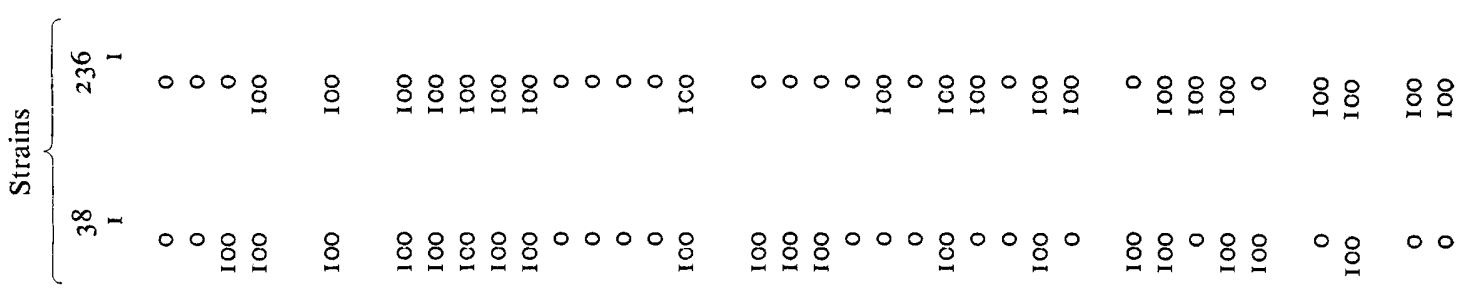

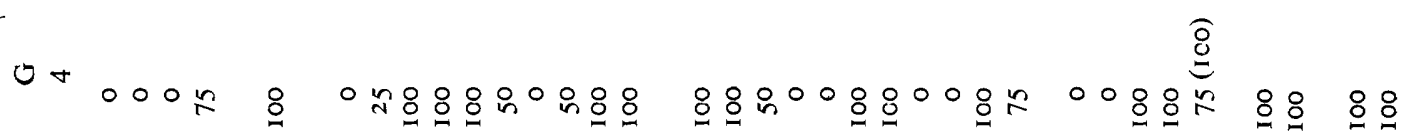
山응

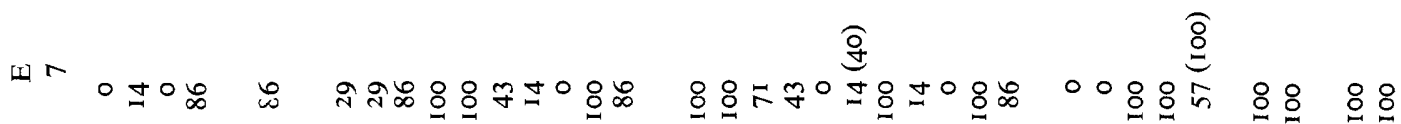

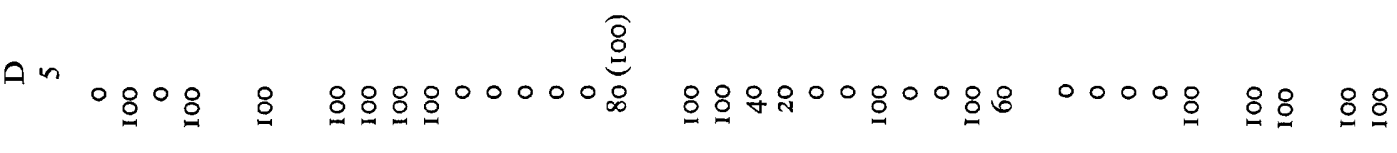

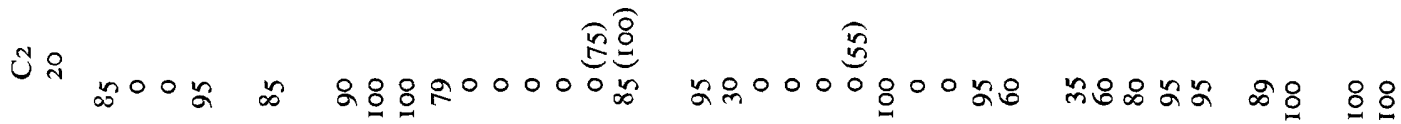
Ut 0008 \& m4

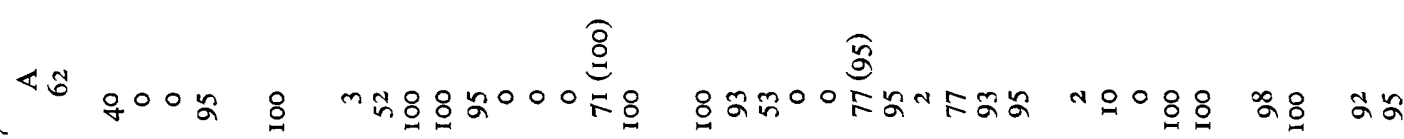
可 in

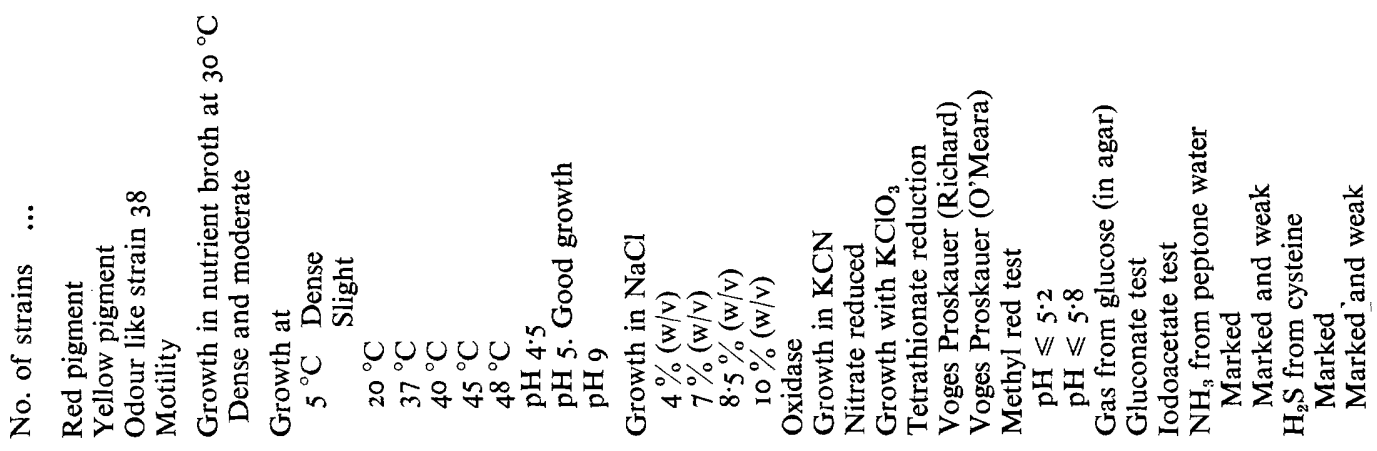




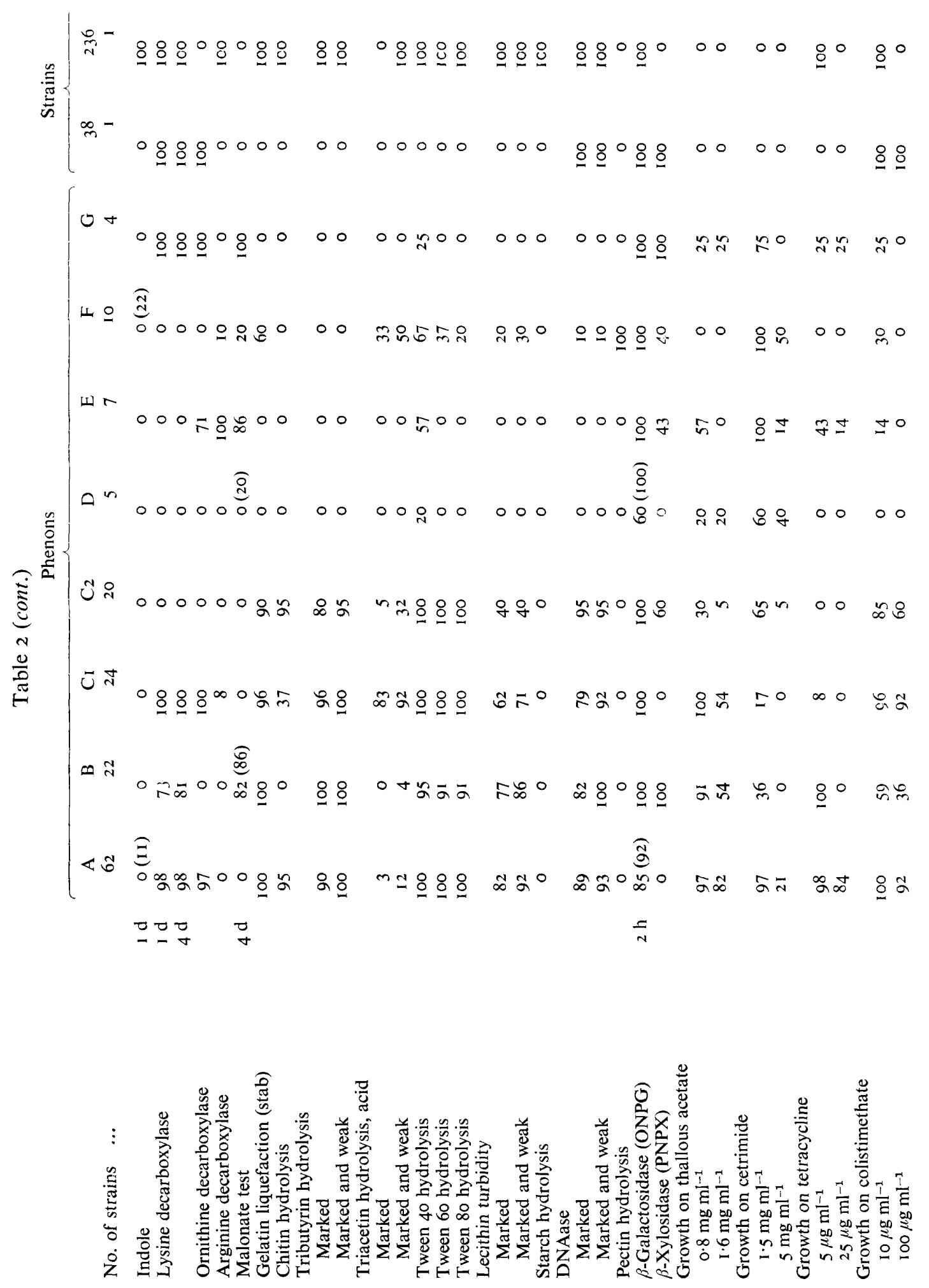


Table 3. Differentiation of subphenons within S. marcescens (numbers of strains positive within 4 days)

\begin{tabular}{llllllll} 
& \multicolumn{7}{c}{ Subphenons } \\
& A1 & A2 & A3 & A4 & A5 & A6 & A8 \\
No. of strains & 9 & 9 & 8 & 7 & 5 & 2 & 5 \\
Red pigment & 9 & 9 & 0 & 0 & 0 & 2 & 0 \\
Carbon source utilization & & & & & & & \\
$\quad$ meso-Erythritol & 9 & 9 & 8 & 7 & 0 & 2 & 0 \\
$\quad$ Quinate & 0 & 0 & 0 & 7 & 5 & I (2) & 5 \\
4-Hydroxybenzoate & 0 & 0 & 0 & 7 & 5 & 2 & $4^{*}$ \\
$\quad$ Carnitine & 7 & $5(8)$ & 3 & $6(7)$ & 5 & 1 & 0 \\
$\quad$ Benzoate & 9 & 0 & 0 & 0 & 0 & 0 & 0 \\
$\quad$ Hippurate & $5(9)$ & 0 & 0 & 0 & 0 & 0 & 0 \\
$\quad$ 3-Hydroxybenzoate & 0 & 0 & 8 & 0 & 0 & 0 & 2 \\
$\quad$ Trigonelline & 0 & 0 & 2 & 0 & $1(5)$ & 0 & 5 \\
Tetrathionate reduction & 9 & 9 & 8 & 0 & 5 & 2 & 5
\end{tabular}

Numbers in parentheses indicate total numbers positive after 16 days, if different from the numbers after 4 days.

* The fifth strain gave a doubtful result.

Table 4. Differentiation of subphenons within S. marinorubra (numbers of strains positive within 4 days)

\begin{tabular}{lccc} 
& \multicolumn{3}{c}{ Subphenons } \\
\cline { 2 - 4 } No. of strains & BI & B2 & B3 \\
$\begin{array}{l}\text { Carbon source utilization } \\
\quad \text { D-Melezitose }\end{array}$ & 3 & 3 \\
Sarcosine & 2 & 3 & 3 \\
Benzoate & (I2) & 3 & $(3)$ \\
Ethanol & I0 (I2) & 3 & I \\
D-Tartrate & 0 & 3 & 0 \\
Histamine & I I (12) & 0 & 2 \\
Benzylformate & 4 & 0 & 3 \\
Voges Proskauer (O'Meara) & I I & 2 & 0 \\
Lysine decarboxylase & I 2 & 0 & 2 \\
Malonate test & I I (12) & 3 & 0 \\
Lecithin turbidity in 5 days & I2 & 3 & 0 \\
\end{tabular}

Numbers in parentheses indicate total numbers positive after 16 days, if different from the numbers after 4 days.

* Weak reaction.

$70 \% \mathrm{~S}$ level, together with the unidentified isolate 38 (see Discussion). Differential characters of Serratia species are given in Table 7. Included in this Table are the known GC base ratios; those of phenon $A$ are about $58 \%$ and those of phenons $C_{I}$ and $C_{2}$ are about 54 to $56 \%$. Only two values are available for strains of phenon $\mathbf{B}$.

The representatives of other genera (phenons D to $G$ ) were clearly separated in the dendrogram from phenons $\mathrm{A}$ to $\mathrm{C}$, and their identities are noted below.

Phenon $D$. This contained five yellow-pigmented strains including the proposed neotype of Enterobacter agglomerans (E20, Chromobacterium typhiflavum; see Ewing \& Fife, I972) also 
Table 5. Differentiation of subphenons within S. liquefaciens (numbers of strains positive within 4 days)

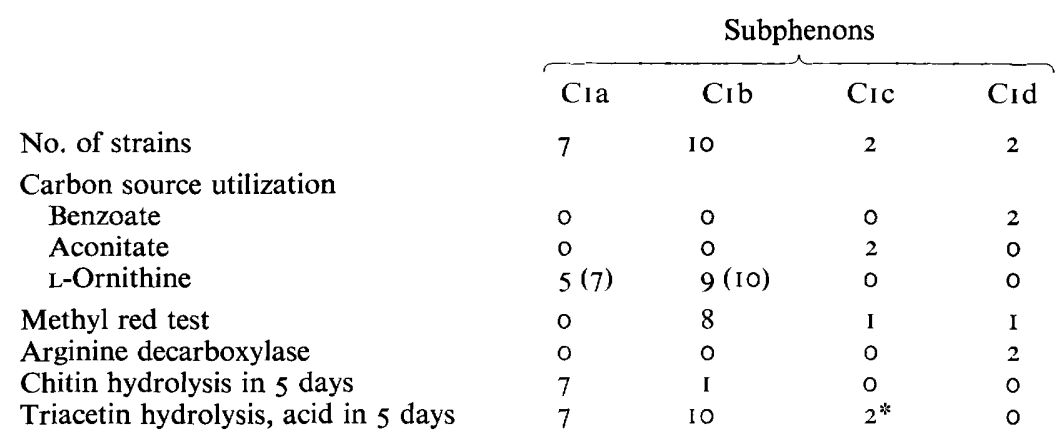

Numbers in parentheses indicate total numbers positive after 16 days, if different from the numbers after 4 days.

* Weak reaction.

Table 6. Differentiation of subphenons within S. plymuthica (numbers of strains positive within 4 days)

No. of strains
Carbon source utilization
Inulin
Benzoate
Betaine
Benzylformate
Glycerol
Aconitate
Glycerate
Lactate
Acetate
2-Ketoglutarate
Sorbitol

Dense growth in nutrient broth in $24 \mathrm{~h}$ at $30^{\circ} \mathrm{C}$ $\beta$-Xylosidase

\begin{tabular}{|c|c|c|}
\hline \multicolumn{3}{|c|}{ Subphenons } \\
\hline $\mathrm{C} 2 \mathrm{a}$ & $\mathrm{C}_{2} \mathrm{~b}$ & $\mathrm{C} 2 \mathrm{c}$ \\
\hline 4 & I I & 5 \\
\hline $\begin{array}{c}4 \\
(4)\end{array}$ & $\begin{array}{c}\text { I } \\
(2)\end{array}$ & $\begin{array}{l}\text { I } \\
\text { O }\end{array}$ \\
\hline 4 & I & 0 \\
\hline 4 & 2 & 0 \\
\hline 4 & II & I \\
\hline 4 & 11 & 0 \\
\hline 4 & 11 & 1 \\
\hline 4 & II & I \\
\hline 4 & 10 & 0 \\
\hline 4 & 8 & o \\
\hline 4 & 2 & 4 \\
\hline 4 & $9(\mathrm{IO})^{*}$ & $(3)^{*}$ \\
\hline 0 & 8 & 5 \\
\hline
\end{tabular}

Numbers in parentheses indicate total numbers positive after 16 days.

* Dense and moderate growth.

commonly called Erwinia herbicola (Löhnis I9I I) Dye 1964. This phenon formed at the $90 \%$ $\mathrm{S}$ level and was homogeneous.

Phenon E. This contained seven strains at the $80 \% \mathrm{~S}$ level. It could be divided into two subphenons, EI and E2, and a single yellow-pigmented strain (CIP57-33). Subphenon E2 included the proposed neotype of Enterobacter cloacae (CIP60-86) and subphenon Er was composed of two strains labelled Erwinia nimipressuralis. Differential characteristics of the subphenons are given in Table 8.

Phenon $F$. This was composed of io pectinolytic strains ('pectobacteria'), with subphenons corresponding to Erwinia carotovora var. atroseptica $(\mathrm{FI})$. E. carotovora var. carotovora $\left(\mathrm{F}_{2}\right)$ and $E$. chrysanthemi $\left(\mathrm{F}_{3}\right)$. Differential characteristics are given in Table 9.

Phenon $G$. This was composed of four strains, including the proposed neotype of Enterobacter aerogenes (also called Klebsiella mobilis by Bascomb et al., I97I). 


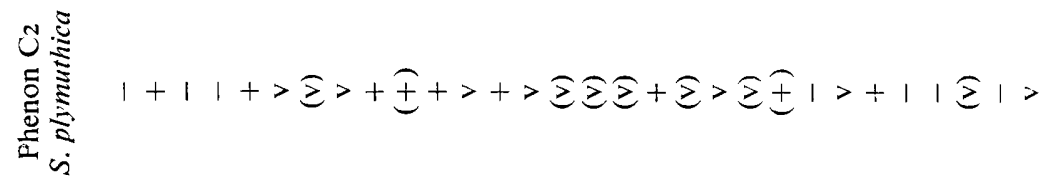
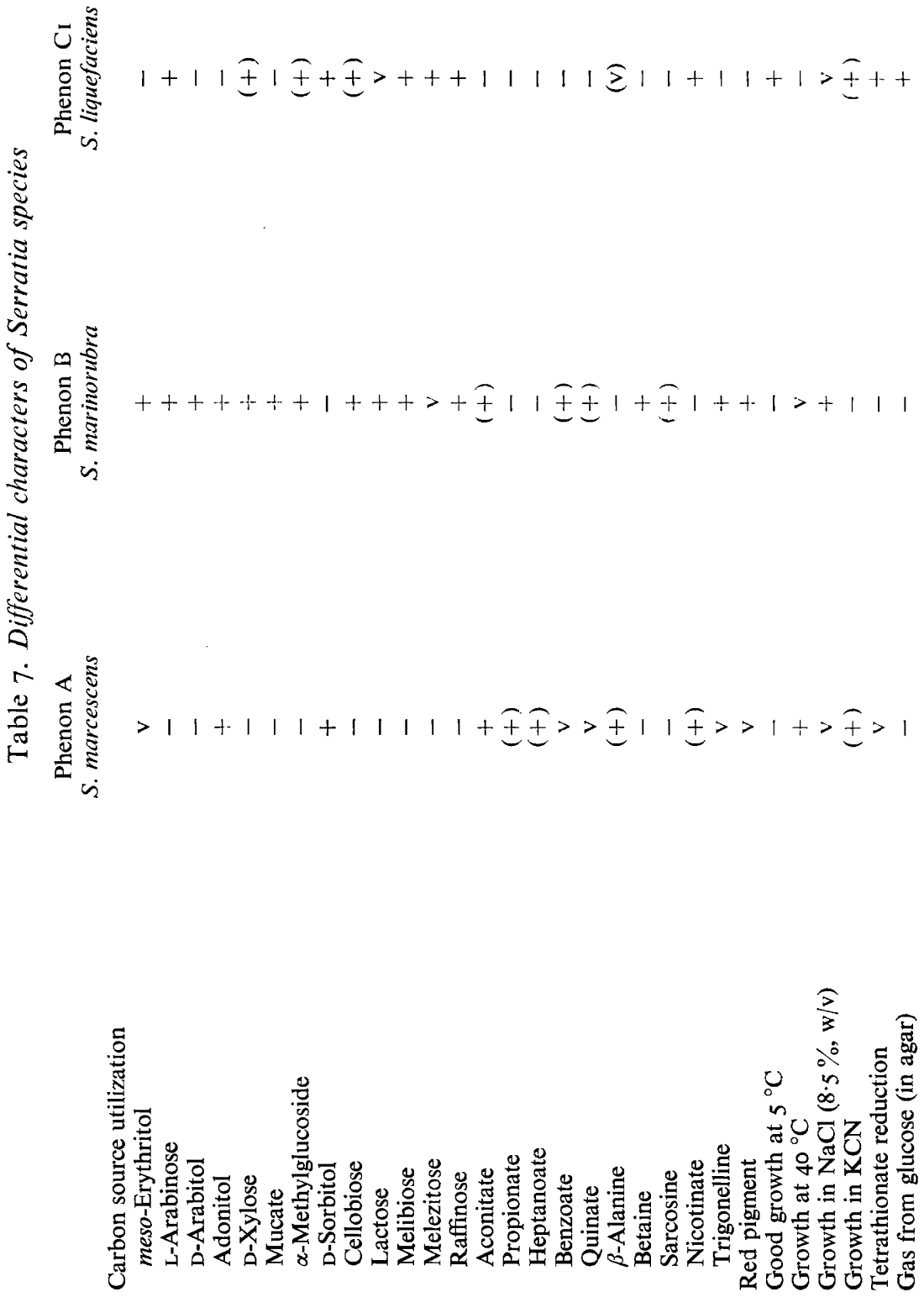


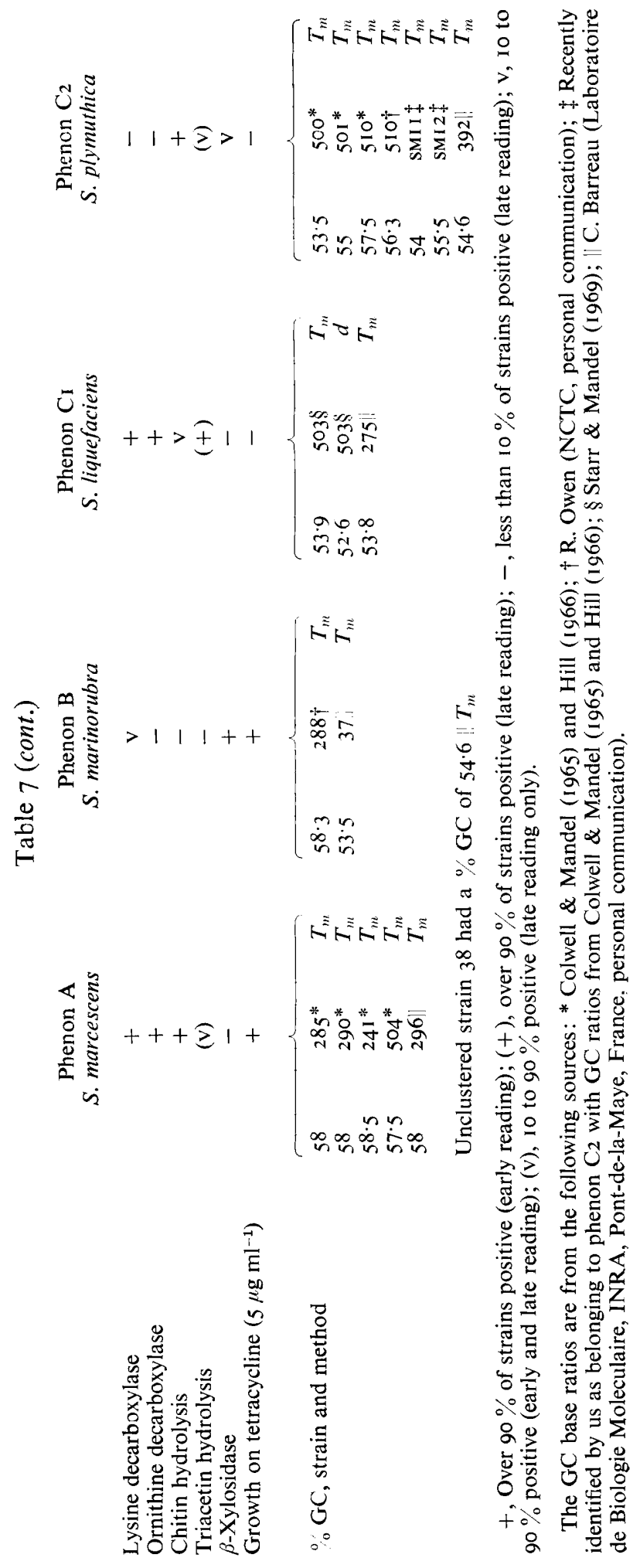


Table 8. Differentiation of subphenons within Enterobacter cloacae (numbers of strains positive within 4 days)

$\overbrace{\mathrm{E}_{\mathbf{I}}}^{\text {Subphenons }} \underbrace{}_{\mathrm{E}_{2}}$

No. of strains

Ent. nimipressuralis

Typical Ent. cloacae

Carbon source utilization

$\alpha$-Methylglucoside

2

4

Kynurenate

Sucrose

Growth at $5{ }^{\circ} \mathrm{C}$

Growth in $\mathrm{NaCl}(8.5 \%$, w/v)

Growth with thallous acetate $\left(0.8 \mathrm{mg} \mathrm{ml}^{-1}\right)$

$\begin{array}{ll}0 & 3(4) \\ 0 & 2(4) \\ 0 & 4 \\ 2 & 0 \\ 0 & 4 \\ 0 & 4\end{array}$

Numbers in parentheses indicate total numbers positive after 16 days, if different from the numbers after 4 days.

Table 9. Differentiation of subphenons within the 'pectobacteria' (numbers of strains positive within 4 days)

No. of strains

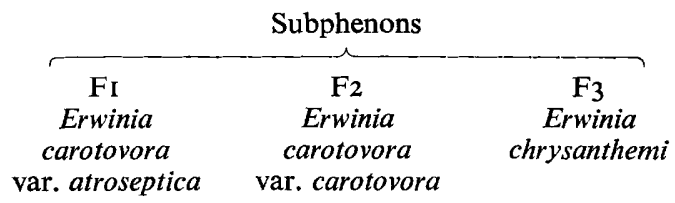

Carbon source utilization

L-Rhamnose

$\alpha$-Methylglucoside

L-Serine

meso-Tartrate

Trehalose

Acetate

Dense growth in nutrient broth in $24 \mathrm{~h}$ at $30^{\circ} \mathrm{C}$

3
3
3
0
0
3
0
0

3

2

Growth at
$5{ }^{\circ} \mathrm{C}$
$37^{\circ} \mathrm{C}$
$40^{\circ} \mathrm{C}$
pH 5
pH 9

$\begin{array}{ccc}3 & 3 & 0 \\ 3 & 0 & 0 \\ 0 & 3 & 2 \\ 0 & 0 & (2) \\ 3 & 3 & 0 \\ 0 & (3) & (1) \\ 0 & 2(3)+ & 2 \\ & & \\ 3 & (1) \S & 0 \\ 0 & 3 & 2 \\ 0 & 0 & 2 \\ (1)^{*} & (1) & 2 \\ (1)^{*} & 3 & (2)^{*} \\ 0 & 3 & 0 \\ 0 & 0 & 2 \\ 0 & 3 & 2 \\ 0 & 0 & (2) \dagger \\ 0 & 0 & 2 \\ 0 & 2 & 2 \\ 0 & 3 & 2 \\ 0 & 0 & 2 \\ 0 & 0 & 2 \\ 0 & 2 & 2\end{array}$

Growth in $\mathrm{NaCl}(7 \%$ w/v)

Gas from glucose (in agar)

Voges Proskauer (Richard)

Indole production

Malonate test

Gelatin hydrolysis

Tween 40 hydrolysis

Tween 80 hydrolysis

Lecithin turbidity

$\beta$-Xylosidase

Numbers in parentheses indicate total numbers positive after $\mathrm{I} 6$ days, except: ${ }^{*}$ after 6 days; $\uparrow$ after 5 days.

$\$$ Moderate and dense growth.

$\S$ Absorbance between 0.03 and 0.30 . 
Table I0. Differentiation of the higher ranked groups

$\begin{array}{lccccc}\text { Carbon source utilization } & \begin{array}{c}\text { Genus } \\ \text { Serratia }\end{array} & \begin{array}{c}\text { Erwinia } \\ \text { herbicola }\end{array} & \begin{array}{c}\text { Enterobacter } \\ \text { cloacae }\end{array} & \text { 'Pectobacteria } & \begin{array}{c}\text { Klebsiella } \\ \text { mobilis }\end{array} \\ \begin{array}{l}\text { L-Rhamnose } \\ \text { D-Glucosamine }\end{array} & - & + & + & \mathrm{v} & + \\ \text { D-Glucuronate } & + \text { or }(+) & + & \mathrm{v} & \mathrm{v} & - \\ \text { Maltose } & + \text { or }(+) & + & + & - & + \\ \text { Caprylate } & + & + & + & - & + \\ \text { L- and D-Alanine } & + \text { or }(+) & - & - & - & - \\ \text { 4-Aminobutyrate } & + \text { or }(+) & \mathrm{v} & (+) & - & + \\ \text { L-Proline } & + \text { or }(+) & (+) & (\mathrm{v}) & - & (\mathrm{v}) \\ \text { L-Tyrosine } & + & + & + & - & + \\ \text { Kynurenate } & + \text { or }(+) & - & - & - & (+) \\ \text { Putrescine } & + \text { or }(+) & - & \mathrm{v} & - & + \\ \text { Yellow pigment } & + & - & \mathrm{v} & - & + \\ \text { Gluconate test } & - & + & \mathrm{v} & - & - \\ \text { Iodoacetate test } & + & - & + & - & + \\ \text { Arginine decarboxylase } & + & + & (+) & - & (+) \\ \text { Gelatin hydrolysis } & + & - & + & \mathrm{v} & - \\ \text { Tributyrin hydrolysis } & + \text { or }(+) & - & - & - & - \\ \text { Tween 60 or 80 } & + & - & - & \mathrm{v} & - \\ \text { DNAase } & + \text { or }(+) & - & - & \mathrm{v} & - \\ \text { Pectin hydrolysis } & - & - & - & + & -\end{array}$

+ , Over $90 \%$ of strains positive (early reading); $(+)$, over $90 \%$ of strains positive (late reading); - , less than $10 \%$ of strains positive (late reading); v, Io to $90 \%$ positive (early and late reading); (v), Io to $90 \%$ positive (late reading only).

Table I I. Vigour values of the clusters based on all characters excluding invariant ones

$\begin{array}{llccc} & & \text { Range } & \text { Mean } & \text { S.D. } \\ \text { A. Serratia marcescens } & 0.439-0.63 \mathrm{I} & 0.568 & 0.038 \\ \text { B. Serratia marinorubra } & 0.548-0.647 & 0.6 \mathrm{I} I & 0.026 \\ \text { C1. Serratia liquefaciens } & 0.519-0.594 & 0.567 & 0.02 \mathrm{I} \\ \text { C2. Serratia plymuthica } & 0.347-0.602 & 0.514 & 0.066 \\ \text { D. Erwinia herbicola } & 0.28 \mathrm{I}-0.380 & 0.335 & 0.043 \\ \text { E. Enterobacter cloacae } & 0.369-0.479 & 0.419 & 0.050 \\ \text { F. 'Pectobacteria' } & 0.178-0.347 & 0.262 & 0.050 \\ \text { G. Klebsiella mobilis } & 0.564-0.621 & 0.598 & 0.028 \\ & \text { Strain 38 } & - & 0.513 & - \\ & \text { Strain 236 } & - & 0.435 & -\end{array}$

Two strains were not included in any cluster. Strain 38 remains unidentified (see Discussion). Strain 236 was received as Serratia but was subsequently identified as Aeromonas hydrophila, and was typical of this species in a numerical study (Popoff \& Véron, 1976). It was rather close to the Serratia group on the UPGMA phenogram with $S_{S M}$, but not on the other phenograms.

A summary of characteristics allowing differentiation of Serratia from other groups is given in Table 10. Starr \& Mandel (1969) cite the GC base ratios of strains of phenons E and $\mathrm{G}$ as between 53 and $55^{\cdot 5}$, so no distinction can be made on this basis (see also Table 7 ).

\section{Comparison of numerical methods}

The single linkage method gave similar results to UPGMA except that phenons $C_{I}$ and C2 were not so sharply separated (though they were still distinct). Subphenons were not clearly seen in phenon A, but could be recognized in other phenons. Strain 222 was not included 
Table 12. Parameters of phenons

Values of $\bar{d}_{c j}=\Sigma d_{c j} / t_{J}, s_{d c j}=\sqrt{ }\left[\Sigma\left(d_{c j}-\bar{d}_{c j}\right)^{2} /\left(t_{J}-\mathbf{I}\right)\right]$, and $r_{J}=\bar{d}_{c j}+k s_{d c j}$ (with $\left.k=\mathrm{I} \cdot 96\right)$ were calculated by the methods given in Sneath (1974).

$\begin{array}{lccccc}\text { Phenon } & \begin{array}{c}\text { No. of } \\ \text { strains }\end{array} & \begin{array}{c}\text { No. of } \\ \text { characters }\end{array} & \bar{d}_{c j} & s_{d c j} & r_{J} \\ \text { A } & 62 & 244 & 0.230 & 0.0488 & 0.326 \\ \text { B } & 22 & 244 & 0.210 & 0.0441 & 0.296 \\ \text { CI } & 24 & 244 & 0.202 & 0.0389 & 0.278 \\ \text { C2 } & 20 & 244 & 0.266 & 0.0413 & 0.347 \\ \text { D } & 5 & 244 & 0.18 \text { I } & 0.0309 & 0.242 \\ \text { E } & 7 & 244 & 0.241 & 0.0399 & 0.319 \\ \text { F } & 10 & 244 & 0.229 & 0.0377 & 0.303 \\ \text { G } & 4 & 244 & 0.194 & 0.0485 & 0.289 \\ \text { Strain 38 } & \text { I } & 240 & - & - & - \\ \text { Strain 236 } & \text { I } & 239 & - & - & -\end{array}$

in phenon A, but was distantly attached to phenons A-C. Strain CIP57-33 was separated from phenon $\mathrm{E}$, and distantly attached to phenon $\mathrm{F}$. The co-phenetic correlation was 0.87 .

The square of the complement of the simple matching coefficient can be partitioned into the square of the difference in vigour, $D_{V}{ }^{2}$, and the square of the difference in pattern $D_{P}{ }^{2}$ (Sneath, I968). Vigour is the frequency of positive characters. The lowest values of vigour are shown by the pectobacteria and the highest by phenon B (Table II). Although there are marked differences in vigour, its removal did not greatly alter the resemblances between strains, so the differences between the clusters are not due solely to differences in vigour; UPGMA clustering on $D_{P}$ gave a phenogram similar to Fig. I. There were few changes within the phenons when the vigour component was removed. Subphenon A8 was divided into two minor groups depending on ability to utilize 3-hydroxybenzoate. Subphenons within phenon $\mathrm{E}$ were recovered with the exclusion of strain $\mathrm{C}_{2}$ (CIP57-33) from the phenon. Within phenon $\mathrm{F}$ a tighter grouping of strains labelled Erwinia chrysanthemi $\left(\mathrm{F}_{3}\right)$ was observed. At the level of $0.30 D_{P}$ two major groups of phenons were formed: one contained phenons $\mathrm{A}, \mathrm{C}_{1}$ and $\mathrm{C}_{2}$; and the other phenons B, D, E, F, G, and strain 38. Strain 236 was not closely related to any group. The co-phenetic correlation was 0.89 . Single linkage on $D_{P}$ gave very similar results to single linkage on $S_{S M}$.

Cluster parameters. The centrotype of each cluster, i.e. the strain closest to the centroid, is noted in Table I. The most dispersed phenon was $\mathrm{C}_{2}$ and the most compact was phenon D as shown by $r_{J}$ (Table I2).

\section{DISCUSSION}

The results support a genus Serratia consisting of four taxa, corresponding to phenons A, $\mathrm{B}, \mathrm{CI}$ and $\mathrm{C}_{2}$, which group together in the UPGMA phenogram at the $70 \% \mathrm{~S}$ level. Although phenon B is separated from the other three on the pattern coefficient phenogram, the change in position is slight, and may not be significant; therefore the balance of evidence favours retaining phenon $\mathrm{B}$ with $\mathrm{A}, \mathrm{Cr}$ and $\mathrm{C} 2$. Very little overlap occurs between any of these four phenons, so they should certainly be given species rank. The subphenons, or some of them, could represent valid taxa of low rank which we do not yet have good methods for separating. They may provisionally be referred to as biovars, and may be of epidemiological interest (P. A. D. Grimont, unpublished).

Phenon A corresponds unambiguously to the species presently known as Serratia marcescens Bizio, and no special points arise. 
Three possible epithets for phenon B were found in the literature: stercoraria, rubidaea and marinorubra. Although Serratia stercoraria Jan $1939 a, b$ is rather poorly described, its characteristics are not in conflict with those of phenon B. Bacterium rubidaeum Stapp 1940 shows two discrepancies. Phenon B is the only Serratia species unable to produce acid from sorbitol, but $B$. rubidaeum was sorbitol positive. In addition, $B$. rubidaeum produced a red pigment which differed from prodigiosin: it was non-diffusing and soluble in alcohol and acetone but, unlike prodigiosin, it had an absorption band between 475 and $485 \mathrm{~nm}$ and was insoluble in chloroform, ether, benzene, xylene and toluene. All pigmented strains of phenon $B$ produced a pigment soluble in the latter solvents, with an absorption spectrum similar to that of the pigment of strain NIMA. The pigment of strain 329 resembles that of $B$. rubidaeum, but strain 329 belongs to phenon $\mathrm{C}_{2}$. No authentic strains of $S$. stercoraria or B.rubidaeum are available, so we cannot be sure of their identity. For this reason we are unable to follow the opinions of Ewing et al. (I973) in using the species name Serratia rubidaea (Stapp) Ewing et al. The characters of the 49 cultures placed in S. rubidaea by Ewing et al. (1973) are generally in good accord with those of phenon B. However, four of their strains fermented sorbitol and five failed to ferment adonitol, and, as noted earlier, one strain they considered an atypical $S$. rubidaea is, in our hands, a typical strain of subphenon $\mathrm{C} 2 \mathrm{~b}$.

The only species known to us which definitely corresponds to phenon B is Serratia marinorubra ZoBell and Upham 1944. A monotype (strain 288, ATCC276I4, NCTCI0912) has been preserved; and it agrees with the original description. Although it is not a typical strain of phenon B using $S_{S M}$, this appears to be due principally to its rather slow rate of growth and low vigour, because it is quite typical of phenon B as judged by the $D_{P}$ coefficient. In the $D_{P}$ phenogram strain 288 was attached to subphenon BI. We recommend Serratia marinorubra ZoBell and Upham 1944 for phenon B, which is an unambiguous name.

Although strains of phenon $\mathrm{CI}$ are non-pigmented, we believe this phenon should be included in the genus Serratia. It is phenetically even closer to $S$. marcescens than are phenons $\mathrm{B}$ and $\mathrm{C}_{2}$, both of which contain red-pigmented strains. The correct name appears to be Serratia liquefaciens (Grimes and Hennerty 193I) Bascomb et al. I97I. It cannot be safely identified with Bacillus noctuarum White 1923 because the strain studied by Weiser \& Lysenko (1956) and named $S$. marcescens var. noctuarum by Lysenko (1958) was not an original strain of White. Authentic strains of Aerobacter liquefaciens Grimes and Hennerty are available and fall into phenon Cı. This organism was later named Aerobacter lipolyticum by Grimes (1961) because the earlier name was then thought to be a later homonym of Aerobacter liquefaciens Beijerinck; however, the Judicial Commission (1973) in Opinion 48 rejected Beijerinck's name as a nomen dubium, thus removing the bar to the validity of A. liquefaciens Grimes and Hennerty.

Ewing (1963) had earlier transferred Grimes and Hennerty's species to Enterobacter as Ent. liquefaciens, but Bascomb et al. (197I) recognized its close affinity to Serratia and transferred it to that genus. Strain ATCCI4460 (our 503) is the type (co-type according to Sneath \& Skerman, 1966). Ewing et al. (1973) believed that no type strain had been designated and considered ATCCI 4460 was atypical: they therefore proposed a neotype CDCI $284-57$ (our 280). However, there is no need to replace ATCCI 4460 as it is not atypical (it belongs to subphenon CId, as does another original strain, ATCCI446I, that we have recently examined, whereas strain 280 belongs to $\mathrm{CI}$ b), and Grimes indicated that it was the type strain in a personal communication to R. E. Buchanan (American Type Culture Collection, I964).

Phenon $\mathrm{C}_{2}$ occurs most often in fresh water. Several pigmented, aerogenic and coldtolerant species of Serratia from water have been described in the past. Although Hefferan (1906) found that Bacillus miniaceus Zimmermann 1890, Bacillus plymouthensis and Bacter- 
ium kilense were agglutinated by high dilutions of the same sera, it is not certain whether Zimmermann's original strain was, indeed, used and, as no authentic culture now appears available, we cannot be sure of the identity of Serratia miniacea (Zimmermann I 890) Bergey et al. 1923 with phenon $\mathrm{C}_{2}$. Phenon $\mathrm{C}_{2}$ appears identical with Fischer's 'roter Bacillus der Wasserleitung von Plymouth' (Fischer, 1887) and Breunig's Kiel bacillus (Breunig, I888; provided Novy's culture ATCC426I is authentic). The latter was named Bacterium kiliense by Lehmann \& Neumann (I896). It has been ranked as a subspecies, $S$. marcescens subsp. kiliensis, by Ewing et al. (1973), but this is confusing as it was defined only by a negative Voges Proskauer reaction, and phenon $\mathrm{C}_{2}$ strains give both positive and negative reactions. Fischer did not name his red-pigmented aerogenic culture which he isolated from the water supply in Plymouth. The earliest name seems to be Bacillus plymouthensis (Dyar, 1895 ) which is regarded as validly published (Buchanan, Holt \& Lessel, I966). Unfortunately, Dyar did not clearly state he was naming or renaming Fischer's bacillus and the strain he studied was of uncertain origin. This removes the priority of the epithet plymouthensis. Lehmann \& Neumann (I 896) validly published the name Bacterium plymuthicum as follows: 'Bacterium plymuthicum (Fischer) Lehm. et Neum. "Roter Wasserbacillus von Plymouth" Fischer. Genauer beschrieben bei Voges (C.B. XIV, p. 3I4)'. They refer to Fischer and to a newer description by Voges (I893). The sixth edition of Bergey's Manual of Determinative Bacteriology (Breed, Murray \& Hitchins, 1948) transferred this species to the genus Serratia as $S$. plymuthicum. The epithet can be corrected to plymuthica without change in priority and we prefer it for phenon $\mathrm{C}_{2}$ to kiliensis of the same date (Serratia kiliensis Bergey et al. 1923) because Fischer's bacillus is better authenticated and a cause of less confusion. ATCCI 83 is the monotype. This strain is now discarded from the ATCC, but cultures derived from it exist (сCм640, our 510).

Strain 38 is apparently a single representative of an unknown species. In the $D_{P}$ phenogram, it was loosely attached to Erwinia herbicola. It resembles the 'lysine-positive Citrobacter' of Leclerc \& Buttiaux (1965), whose DNA showed $47 \%$ relatedness to DNA from Serratia marcescens (Crosa et al., 1974), but little other taxonomic information is available.

The representatives of other genera were only included to provide some bounds to the genus Serratia. Phenon E corresponds to Enterobacter cloacae (Jordon) Hormaeche and Edwards 1960; distinctive properties of Erwinia nimipressuralis Carter 1945 are few (Table 8), so it is doubtful whether it deserves species rank. One yellow-pigmented strain of Enterobacter cloacae was included (strain C2, CIP57-33), and its low similarity to the other strains of this species would support the view of Brenner (1973) that the DNA of pigmented and non-pigmented Enterobacter cloacae are only distantly related. In phenon $F$ the three organisms Erwinia carotovora (Jones) Bergey et al. 1923, Erwinia atroseptica (Van Hall) Jennison 1923, and Erwinia chrysanthemi Burkholder, McFadden and Dimock 1953 are very close but can be differentiated.

This study also raises a question of taxonomic usage: how strict should one be in reviving old, and often forgotten, names? As one looks for earlier and earlier names, one usually finds the descriptions become poorer, but equally there are also fewer properties recorded that definitely disagree with characters of the strains under study. The description of Bacterium plymuthicum was found to fit phenon $\mathrm{C} 2$, but Bacillus miniaceus would fit almost as well. If authentic cultures are not available we believe one should be cautious in making an identification, particularly if the original description is poor. In our opinion, the only sure criterion is comparison with an original type culture, and in the absence of such cultures identifications are only too often matters of faith. 
We are grateful to S. P. Lapage, L. Le Minor, B. Holmes, R. Johnson and M. Véron for helpful advice and to M. J. Sackin for assistance with computing. We also thank R. Owen and C. Barreau for GC determinations, and numerous individuals who provided strains. One of us (P.A.D.G.) acknowledges the assistance of the British Council for a travelling bursary.

\section{REFERENCES}

American Type Culture Collection (1964). Catalogue of Cultures, 7 th edn. Rockville, Maryland: American Type Culture Collection.

American Type Culture Collection (1974). Catalogue of Strains, i ith edn. Rockville, Maryland: American Type Culture Collection.

BARritT, M. M. (1936). The intensification of the Voges-Proskauer reaction by the addition of $\alpha$-naphthol. Journal of Pathology and Bacteriology 42, $44 \mathrm{I}-454$.

Bascomb, S., Lapage, S. P., Willcox, W. R. \& CuRTis, M. A. (I97I). Numerical classification of the tribe Klebsielleae. Journal of General Microbiology 66, 279-295.

Bascomb, S., LAPAGE, S. P., CuRTiS, M. A. \& Willcox, W. R. (1973). Identification of bacteria by computer: identification of reference strains. Journal of General Microbiology 77, 291-315.

Bergey, D. H., Harrisson, F. C., Breed R. S., Hammer, B. W. \& Huntoon, F. M. (1923). Bergey's Manual of Determinative Bacteriology, Ist edn. Baltimore: The Williams and Wilkins Co.

Breed, R. S., Murray, E. G. D. \& Hitchins, A. P. (1948). Bergey's Manual of Determinative Bacteriology, 6th edn. Baltimore: The Williams and Wilkins Co.

BRENNER, D. J. (1973). Deoxyribonucleic acid reassociation in the taxonomy of enteric bacteria. International Journal of Systematic Bacteriology 23, 298-307.

Breunig J. (1888). Bacteriologische Untersuchung des Trinkwassers der Stadt Kiel im August und September. Dissertation, University of Kiel.

Brisou, B., Richard, C. \& Lenriot, A. (1972). Intérêt taxonomique de la recherche de la $\beta$-xylosidase chez les Enterobacteriaceae. Annales de l'Institut Pasteur 123, 341-347.

Brisou, J. \& Cadeillan, J. (1959). Étude sur les Serratia. A propos de quatre souches isolées en médecine vétérinaire. Bulletin de l'Association des diplomés de microbiologie de la Faculté de pharmacie de Nancy 75, 34-39.

Buchanan, R. E. \& Gibbons, N. E. (I974). (Editors.) Bergey's Manual of Determinative Bacteriology, 8th edn. Baltimore: The Williams \& Wilkins Co.

Buchanan, R. E., Holt, J. G. \& Lessel, E. F. (1966). Index Bergeyana. Baltimore: The Williams \& Wilkins Co.

Burkholder, W. H., McFadden, L. A. \& Dimock, A. W. (1953). A bacterial blight of chrysanthemums. Phytopathology 43, 522-526.

CARTER, J. C. (1945). Wetwood of elms. Illinois Natural History Survey Bulletin 23, 407-448.

Colwell, R. R. \& MANDel, M. (1965). Adansonian analysis and deoxyribonucleic acid base composition of Serratia marcescens. Journal of Bacteriology 89, 454-46I.

CомвE, E. (1933). Étude comparative de trois bactéries chromogènes à pigment rouge: Serratia marcescens Bizio (Bacillus prodigiosus Flügge), Serratia kiliensis Comité S.B.A. (Bacterium h Breunig), Serratia esseyana n.sp. Combe (Bacille rouge d'Essey Lasseur). Thèse de Pharmacie, Nancy.

Crosa, J. H., Steigerwalt, A. G., Fanning, G. R. \& Brenner, D. J. (1974). Polynucleotide sequence divergence in the genus Citrobacter. Journal of General Microbiology $\mathbf{8 3}, 27 \mathbf{I}-\mathbf{2 8 2}$.

Duran-Reynals, F. \& Clausen, H. J. (1937). A contagious tumour-like condition in the lizard (Anolis equestris) as induced by a new bacterial species, Serratia anolium (sp.n.). Journal of Bacteriology 33, 369-379.

Dyar, H. G. (1895). On certain bacteria from the air of New-York City. Annals of the New York Academy of Sciences 8, 322-380.

Dye, D. W. (1964). The taxonomic position of Xanthomonas trifolii (Huss, 1907) James, 1955. New Zealand Journal of Science 7, 26I-269.

Edwards, P. R. \& EwING, W. H. (1972). Identification of Enterobacteriaceae, 3rd edn. Minneapolis: Burgess Publishing Co.

EISENBERG, J. (I 886). Bakteriologische Diagnostik. Hülfs-Tabellen beim praktischen Arbeiten. Hamburg und Leipzig: Leopold Voss.

EwiNG, W. H. (1963). An outline of nomenclature for the family Enterobacteriaceae. International Bulletin of Bacteriological Nomenclature and Taxonomy $\mathbf{1 3}_{3}, 95-1 \mathrm{I} 0$.

EwING, W. H. \& FIFE, M. A. (1972). Enterobacter agglomerans (Beijerinck) comb.nov. (the herbicolalathyri bacteria). International Journal of Systematic Bacteriology 22, 4-1 I.

Ewing, W. H., Davis, B. R. \& Reavis, R. W. (1959). Studies on the Serratia Group. Atlanta: Center for Disease Control. 
Ewing, W. H., Davis, B. R. \& Johnson, J. G. (1962). The genus Serratia: its taxonomy and nomenclature. International Bulletin of Bacteriological Nomenclature and Taxonomy 12, 47-52.

Ewing, W. H., Davis, B. R. \& FIFE, M. A. (1972). Biochemical Characterization of Serratia liquefaciens and Serratia rubidaea. Atlanta: Center for Disease Control.

Ewing, W. H., Davis, B. R., Fife, M. A. \& Lessel, E. F. (1973). Biochemical characterization of Serratia liquefaciens (Grimes and Hennerty) Bascomb et al. (formerly Enterobacter liquefaciens) and Serratia rubidaea (Stapp) comb.nov. and designation of type and neotype strains. International Journal of Systematic Bacteriology 23, 21 7-225.

FISCHER, B. (I 887). Bacteriologische Untersuchungen auf einer Reise nach Westindien. II. Ueber einen lichtentwickelnden, im Meerwasser gefundenen Spaltpilz. Zeitschrift für Hygiene und Infektionskrankheiten 2, 54-95.

ForTINEAU, L. (I904). L'Erythrobacillus pyosepticus et les bactéries rouges. Thèse de Médecine, Paris.

Fraenkel, D. G. \& Vinopal, R. T. (1973). Carbohydrate metabolism in bacteria. Annual Review of Microbiology 27, 69-100.

Fulton, M., Forney, C. E. \& LeIFson, E. (I959). Identification of Serratia occurring in man and animals. Canadian Journal of Microbiology 5, 269-275.

Grimes, M. (196I). Classification of the Klebsiella-Aerobacter group with special reference to the coldtolerant mesophilic Aerobacter types. International Bulletin of Bacteriological Nomenclature and Taxonomy Ir, I I I-I 29.

Grimes, M. \& HenNerty, A. J. (I93I). A study of bacteria belonging to the subgenus Aerobacter. Scientific Proceedings of the Royal Dublin Society 20 (NS), 89-97.

Grimont, P. A. D. (I969). Les Serratia: étude taxometrique. Thèse de Médecine, Bordeaux.

Grimont, P. A. D. \& Dulong De Rosnay, H. L. C. (1972). Numerical study of 60 strains of Serratia. Journal of General Microbiology 72, 259-268.

Hamon, Y., Le Minor, L. \& Peron, Y. (1970). Les bactériocines d'Enterobacter liquefaciens. Comptes Rendus hebdomadaire des séances de l'Académie des Sciences, Paris 270, 886-889.

Hankin, L., Zucker, M. \& SANDs, D. C. (I97I). Improved solid medium for the detection and enumeration of pectolytic bacteria. Applied Microbiology 22, 205-209.

Haynes, W. C. (1951). Pseudomonas aeruginosa - its characterization and identification. Journal of General Microbiology 5, 939-950.

Hefferan, M. (1903, I904). A comparative and experimental study of bacilli producing red pigment. Zentralblatt für Bakteriologie, Parasitenkunde, Infektionskrankheiten und Hygiene (Abteilung II) II, 3 II $-317,397-404,456-475,520-540$.

Hefferan, M. (1906). Agglutination and biological relationship in the prodigiosus group. Zentralblatt für Bakteriologie, Parasitenkunde, Infektionskrankheiten und Hygiene (Abteilung I) Orig. 4r, 553-562.

Hill, L. R. (1966). An index to deoxyribonucleic acid base composition of bacterial species. Journal of General Microbiology 44, 4I9-437.

Hormaeche, E. \& EDwards, P. R. (I960). A proposed genus Enterobacter. International Bulletin of Bacteriological Nomenclature and Taxonomy ro, $71-74$.

Hugh, R. \& Leifson, E. (1953). The taxonomic significance of fermentative versus oxidative metabolism of carbohydrates by various Gram negative bacteria. Journal of Bacteriology 66, 24-26.

Hugo, W. B. \& Beveridge, E. G. (1962). A quantitative and qualitative study of the lipolytic activity of single strains of seven bacterial species. Journal of Applied Bacteriology 25, 72-82.

JAN, A. (1939a). Biologie et chrontogénèse chez deux bactéries nouvelles du genre Serratia. Thèse d'Université (Pharmacie), Paris.

JAN, A. (1939b). Biologie et chromogénèse chez deux bactéries nouvelles du genre Serratia. Bulletin de la Société scientifique de Bretagne 16, 27-34.

Jennison, H. M. (1923). Potato blackleg with special reference to the etiological agent. Reports from the Missouri Botanical Garden ro, I-72.

Judicial Commission (1973). Opinion 48. Rejection of the name Aerobacter liquefaciens Beijerinck and conservation of the name Aeromonas Stanier with Aeromonas hydrophila as the type species. International Journal of Systematic Bacteriology 23, 473-474.

Kovacs, N. (1956). Identification of Pseudomonas pyocyanea by the oxidase reaction. Nature, London 178, 703.

LeClerc, H. \& Buttiaux, R. (1965). Les Citrobacter. Annales de l'Institut Pasteur de Lille 16, 67-74.

LehmanN, K. B. \& Neuman,, R. (I896). Atlas und Grundriss der Bakteriologie und Lehrbuch der Speciellen bakteriologischen Diagnostik, Teil II. Munich: Lehmann.

LeIfSON, E. (I960). Atlas of Bacterial Flagellation. New York: Academic Press.

Le Minor, L. \& Ben Hamida, F. (I962). Avantages de la recherche de la bêta-galactosidase sur celle de la fermentation du lactose en milieu complexe dans le diagnostic bactériologique, en particulier des Enterobacteriaceae. Annales de l'Institut Pasteur 102, 267-277.

le Minor, L., Chippaux, M., Pichinoty, F., Coynault, C. \& Piéchaud, M. (i970). Méthodes simples permettant de rechercher la tétrathionate-réductase en cultures liquides ou sur colonies isolées. Annales de l'Institut Pasteur 119, 733-737. 
Lockhart, W. R. \& Hartman, P. A. (1963). Formation of monothetic groups in quantitative bacterial taxonomy. Journal of Bacteriology 85, 68-77.

LöHNIs, F. (1911). Landwirtschaftlichbakteriologisches Praktikum. Berlin: Borntraeger.

LYSENKO, O. (1958). Contribution to the taxonomy of Coccobacillus acridiorum d'Herelle. Folia biologica 4 , $342-347$.

LySENko, O. (I96I). Pseudomonas - an attempt at a general classification. Journal of General Microbiolcgy 25, 379-408.

MANDEL, M. \& Rownd, R. (1964). Deoxyribonucleic acid base composition in the Enterobacteriaceae: an evolutionary sequence. In Taxonomic Biochemistry and Serology, pp. 585-597. Edited by C. A. Leone. New York: Ronald Press.

Martinec, T. \& Kocur, M. (1960). The taxonomic status of Serratia plymuthica (Lehmann and Neumann) Bergey et al. and of Serratia indica (Eisenberg) Bergey et al. International Bulletin of Bacteriological Nomenclature and Taxonomy 10, 247-254.

Martinec, T. \& Kocur, M. (196I $a$ ). The taxonomic status of Serratia marcescens Bizio. International Bulletin of Bacteriological Nomenclature and Taxonomy 11, 7-12.

Martinec, T \& Kocur, M. (196I $b$ ). A taxonomic study of the members of the genus Serratia. International Bulletin of Bacteriological Nomenclature and Taxonomy II, 73-78.

Martinec, T. \& Kocur, M. (196I c). Contribution to the taxonomic studies of Serratia kiliensis (Lehmann et Neumann) Bergey. International Bulletin of Bacteriological Nomenclature and Taxonomy II, 87-90.

Martinec, T. \& Kocur, M. (I96I $d$ ). Taxonomická studie rodu Serratia. Folia Facultatis Scientiarum Naturalium Universitatis Purkynianae Brunensis 2, 1-77.

Møller, V. (1955). Simplified tests for some amino acid decarboxylases and for the arginine dehydrolase system. Acta pathologica et microbiologica scandinavica 36, 158-172.

National Collection of Industrial Bacteria (1964). Catalogue of Strains, 2nd edn. Edinburgh: Her Majesty's Stationery Office.

O'MeAra, R. A. Q. (I931). A simple, delicate and rapid method of detecting the formation of acetylmethylcarbinol by bacteria fermenting carbohydrate. Journal of Pathology and Bacteriology 34, 40I .

Pichinoty, F. \& PiÉChaud, M. (I968). Recherche des nitrate-réductases bactériennes A et B: méthodes. Annales de l'Institut Pasteur ri4, 77-98.

POPOFF, M. \& VÉRON, M. (1976). A taxonomic study of the Aeromonas hydrophila-Aeromonas punctata group. Journal of General Microbiology 94, I I-220.

Reeves, E. C. R. \& Braithwaite, J. A. (1972). The lactose system in Klebsiella aerogenes v9A. I. Characteristics of two Lac mutant phenotypes which revert to wild type. Genetical Research 20, I75-19I.

RICHARD, C. (1972). Methode rapide pour l'étude des réactions de rouge de méthyle et Voges-Proskauer Annales de l'Institut Pasteur r22, 979-986.

SNeAth, P. H. A. (I957). The application of computers to taxonomy. Journal of General Microbiology I7, 201-226.

SNEATH, P. H. A. (1968). Vigour and pattern in taxonomy. Journal of General Microbiology 54, I-I I.

SNEATH, P. H. A. (1972). Computer taxonomy. Methods in Microbiology 7A, 29-98.

SNEATH, P. H. A. (1974). Test reproducibility in relation to identification. International Journal of Systematic Bacteriology 24, 508-523.

Sneath, P. H. A. \& Skerman, V. B. D. (1966). A list of type and reference strains of bacteria. International Journal of Systematic Bacteriology 16, I-133.

SNeath, P. H. A. \& Sokal, R. R. (I973). Numerical Taxonomy: the Principles and Practice of Numerical Classification. San Francisco: W. H. Freeman.

Sneath, P. H. A. \& Stevens, M. (1967). A divided Petri dish for use with multipoint inoculators. Journal of Applied Bacteriology 30, 495-497.

SokAl, R. R. \& Michener, C. D. (1958). A statistical method for evaluating systematic relationships. Kansas University Science Bulletin 38, $1409-1428$.

STAPP, C. (1940). Bacterium rubidaeum nov.spec. Zentralblatt für Bakteriologie, Parasitenkunde, Infectionskrankheiten und Hygiene (Abteilung II) 102, 25 I-260.

STARR, M. P. \& MANDEL, M. (1969). DNA base composition and taxonomy of phytopathogenic and other enterobacteria. Journal of General Microbiology 56, 113-123.

Stevens, M. (1969). Development and use of multi-inoculation test methods for a taxonomic study. Journal of Medical Laboratory Technology 26, 253-263.

Stuart, C. A., Van Stratum, E. \& Rustigian, R. (1945). Further studies on urease production by Proteus and related organisms. Journal of Bacteriology 49, 437-444.

VÉRoN, M. (1975). Nutrition et taxonomie des entérobactéries. I. Méthodes d'étude des auxanogrammes. Annales de Microbiologie 126A, 267-274.

Voges, O. (I 893). Ueber einige im Wasser vorkommende Pigmentbakterien. Zentralblatt für Bakteriologie, Parasitenkunde, Infektionskrankheiten und Hygiene 14, 30I-3I 5.

WeISER, J. \& LySENKo, O. (1956). Septikemie bource morušového. Československá mikrobiologie 1, 216-222. White, G. F. (1923). Cutworm septicemia. Journal of Agricultural Research 26, 487-496. 
Williams, R. P., Green, J. A. \& Rappoport, D. A. (1956). Studies on pigmentation of Serratia marcescens. I. Spectral and paper chromatographic properties of prodigiosin. Journal of Bacteriology 7I, II5I 20.

ZimmermanN, O. E. R. ( 1890 ). Die Bakterien unserer Trink- und Nutzwässer, insbesondere des Wassers der Chemnitzer Wasserleitung. I. Reihe. Bericht der Naturwissenschaftlichen Gesellschaft zu Chemnitz, i I Bericht, Abh. 3, 53-1 54.

ZoBell, C. E. (1932). Factors influencing the reduction of nitrates and nitrites by bacteria in semi-solid media. Journal of Bacteriology 24, 273-28I.

ZoBell, C. E. \& UPHAM, H. C. (I944). A list of marine bacteria including descriptions of sixty new species. Bulletin of the Scripps Institution of Oceanography 5, 239-28I. 